\title{
MEDIDAS HIDROQUÍMICAS E ISOTÓPICAS EM ÁGUAS SUBTERRÂNEAS QUE ABASTECEM O MUNICÍPIO DE SÃO LUÍS - MARANHÃO
}

\author{
Lucilene Pereira ${ }^{1 a}$ \\ Maria Marlúcia Freitas Santiago ${ }^{1 \mathrm{~b}}$ \\ Luiz Alberto Ribeiro Mendonça ${ }^{1 \mathrm{c}}$ \\ Horst Frischkorn² \\ José Ossian Gadelha de Lima ${ }^{1 \mathrm{~d}}$ \\ Josué Mendes Filho ${ }^{1 e}$
}

\begin{abstract}
RESUMO
As águas subterrâneas no município de São Luís/Maranhão estão, predominantemente, armazenadas nas formações Barreiras e Itapecuru. Medidas hidroquímicas foram utilizadas para entender os processos de recarga dos aqüiferos. Os resultados mostram: (i) águas de baixa salinidade com faixas diferentes de condutividade elétrica e de $\mathrm{pH}$ para cada aqüífero; (ii) influência dos aerossóis marinhos nas águas de recarga do aqüífero Barreiras; (iii) dissolução de carbonatos no aqüífero Itapecuru e (iv) exploração mais intensa do aqüífero Barreiras do que do Itapecuru. As medidas isotópicas mostram: (i) recarga rápida dos dois aqüíferos e (ii) semi-confinamento do aqüífero Itapecuru com recargas regulares.
\end{abstract}

\begin{abstract}
Ground water in the township of São Luís/ Maranhão is principally stored in the formations Barreiras and Itapecuru. We used chemical analyses and environmental isotopes $\left({ }^{18} \mathrm{O}, \mathrm{D}\right)$ in order to understand recharge mechanisms. Results shown: (i) waters are of low salinity, but have electric conductivity and $\mathrm{pH}$ completely different in the two principal aquifers; (ii) marine aerosol plays a role in the mineralization of Barreiras recharge water; (iii) dissolution of carbonate rock is the main contribution in the Itapecuru aquifer; (iv) the Barreiras aquifer is exploited with strong preference; $(v)$ recharge is fast and without effects of evaporation on isotopes; (vi) the Itapecuru aquifer is semi-confined being recharged regularly.
\end{abstract}

Palavras-chave: qualidade de água, isótopos ambientais, aqüifero Itapecuru, aqüífero Barreiras

\section{Introdução}

O município de São Luís é abastecido por cerca de 4000 poços tubulares, dos quais somente 214 são cadastrados pela Companhia de Águas e Esgotos do Maranhão (CAEMA).

O Instituto Brasileiro do Meio Ambiente e dos Recursos Naturais Renováveis (IBAMA), a Gerência Adjunta de Meio Ambiente (GAMA) e o Instituto Municipal de Controle Ambiental (IMCA) estão atuando na área para licenciar, fiscalizar e gerenciar os recursos naturais de São Luís. Atualmente, está sendo feito um diagnóstico ambiental seguido de um levantamento cartográfico com geoprocessamento de toda a ilha. No entanto, poucos dados foram produzidos até agora.

Este trabalho contribuirá para identificação da qualidade e condições de recarga das águas subterrâneas na llha de São Luís, usando hidroquímica e os isótopos

\footnotetext{
1 Departamento de Física da UFC; Tel.: (0xx) 85 288.9913, Fax: (0xx) 85 288.9450; e-mail: (a) lucilene@fisica.ufc.br, (b) marlucia@fisica.ufc.br, (c) larm@fisica.ufc.br, (d) ossian@fisica.ufc.br e (e) josue@fisica.ufc.br.

2 Departamento de Engenharia Hidráulica e Ambiental da UFC; Tel.: (0xx) 85 288.9775, Fax: (0xx) 85 288.9627; e-mail: cariri@ufc.br.
} 
ambientais oxigênio-18 e deutério, fornecendo dados e informações importantes para a gestão dos recursos hídricos subterrâneos na área.
A área pesquisada, de aproximadamente $586 \mathrm{~km}^{2}$, situa-se na região noroeste da llha de São Luís, onde está localizado o município de São Luís (Figura 1).

\section{A área}

Figura 1- Mapa de localização da área e dos poços amostrados (EMBRAPA, modificado).

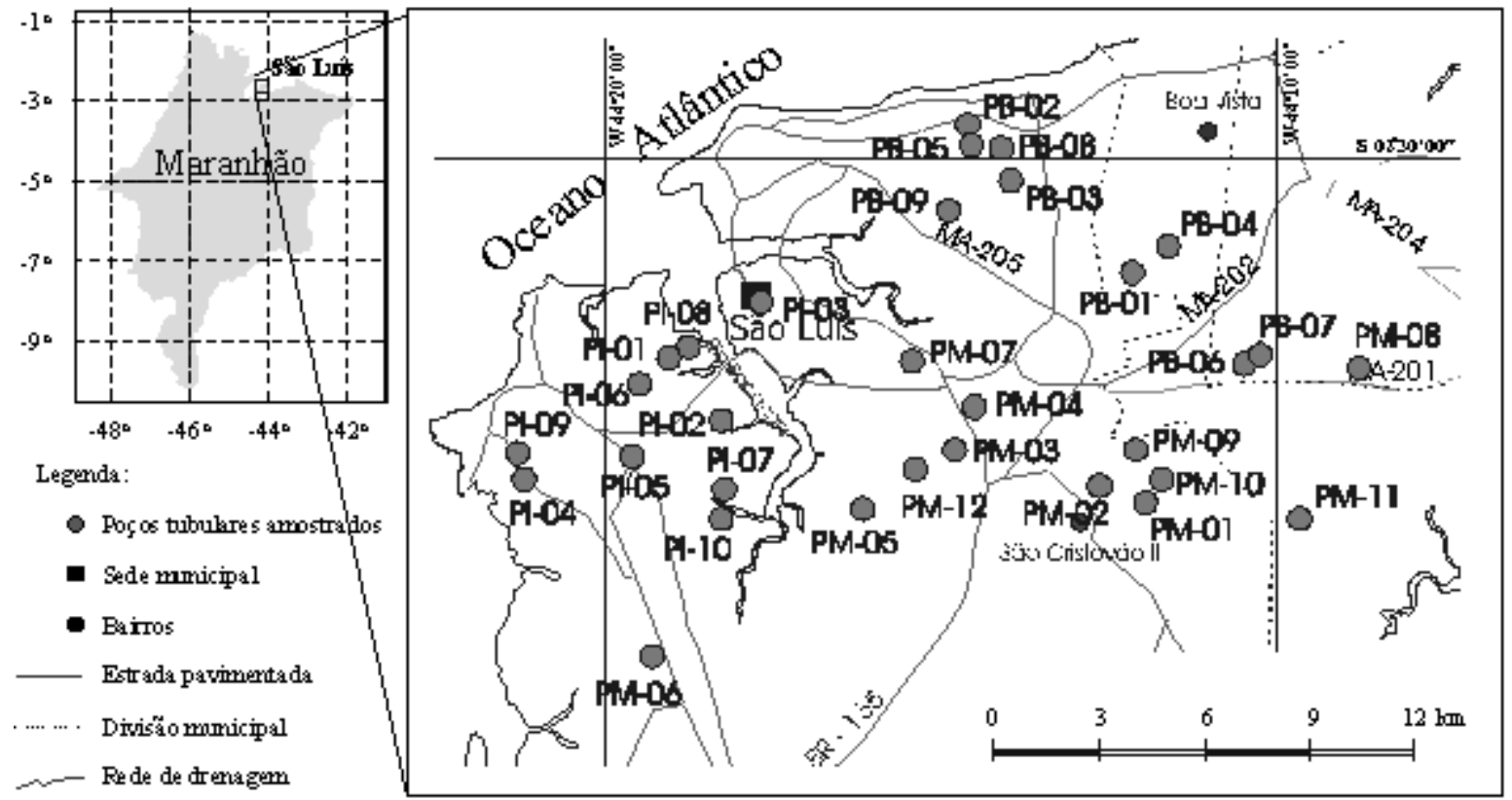

\subsection{Geologia}

A llha de São Luís é situada na Bacia Cratônica de São Luís, formada ao longo dos períodos Cretáceo e Quaternário, constituída pelas formações geológicas Itapecuru, Barreiras, e Açuí (CPRM, 2000).

A Formação Itapecuru - do Cretáceo Superior - aflora localmente na costa oeste da Ilha de São Luís, apresentando estratificações cruzadas e silicificações, principalmente no topo. Intercalam-se leitos de siltitos e folhelhos cinza-esverdeados. Nos perfis litológicos de poços, verifica-se níveis de calcário e calcarenito com intercalações de argilas entre as profundidades de 40 e $145 \mathrm{~m}$ (Pereira, 2002). A espessura máxima desta formação é de $724 \mathrm{~m}$.

A Formação Barreiras - do Terciário aflora, predominantemente, em toda Ilha de São Luís e é constituída de sedimentos clásticos mal selecionados variando de siltitos a conglomerados, com arenitos, em geral, intercalados por lentes de folhelhos. A espessura desta formação varia de 50 a 145 metros, no sentido de oeste para leste da Ilha.
A Formação Açuí - do Quaternário - é constituída por depósitos aluvionares, dunas e solo laterítico. As dunas são areias bem classificadas, desagregáveis, com pequena fração argilosa, o solo laterítico constitui-se de blocos de cimento ferruginoso e matriz quartzosa.

\subsection{Principais aqüíferos}

O sistema hidrogeológico da llha de São Luís constitui-se de dois aqüíferos: (i) o primeiro, livre, o Aqüífero Barreiras, constituído pelos níveis mais arenosos dos depósitos terciários, com espessura variando de 2 a $60 \mathrm{~m}$ no sentido oeste/leste, com nível estático das águas muito variável e de boa produtividade, com vazão específica máxima de $3 \mathrm{~m} / \mathrm{h} / \mathrm{m}$; (ii) 0 segundo, semi-confinado, o Aqüífero Itapecuru, constituído de uma seqüência de sedimentos areno-argilosos, localizado a 40 $\mathrm{m}$ abaixo da superfície, com espessura variando de 20 a $95 \mathrm{~m}$, de baixa produtividade, com vazão específica na faixa de 0,1 a $1,0 \mathrm{~m}^{3} / \mathrm{h} / \mathrm{m}$. Na base deste aqüífero encontra-se uma camada de argila, com cerca de $100 \mathrm{~m}$ de espessura, que constitui 
uma barreira de proteção dos riscos de contaminação por águas salgadas presentes nos aqüíferos subjacentes (Sousa, 2000 e Costa, 1995).

\section{Metodologia}

As águas foram amostradas em 30 poços que captam diferentes aqüíferos, em duas etapas, uma no período chuvoso (abril de 2001) e outro no período seco (novembro de 2001) (Figura 1). A escolha dos poços foi feita a partir de informações verbais do geólogo da CAEMA Afonso Ernani Arraes Braúna. As medidas de condutividade elétrica, $\mathrm{pH}$ e temperatura foram feitas no local durante as coletas.

Os íons maiores $\mathrm{Ca}^{++}, \mathrm{Mg}^{++}, \mathrm{Na}^{+}, \mathrm{K}^{+}$, $\mathrm{Cl}^{-}, \mathrm{SO}_{4}{ }^{=}$e $\mathrm{HCO}_{3}{ }^{-}$foram determinados no Laboratório de Hidroquímica do Departamento de Física da UFC e as medidas de oxigênio-18 e de deutério, no CENA (Centro de Energia Nuclear na Agricultura - Piracicaba/SP).

As medidas de oxigênio e deutério são feitas em relação ao padrão internacional VSMOW (Vienna Standard Mean Ocean Water) e expressas em "delta por mil":

$$
\delta\left({ }^{\circ}{ }_{\text {oo }}\right)=\frac{R_{\text {amostra }}-R_{\text {padrão }}}{R_{\text {padrão }}} \times 10^{3}
$$

onde $R$ é a razão isotópica, entre os isótopos pesados $\left({ }^{18} \mathrm{O}\right.$ ou $\left.\mathrm{D}\right)$ e os mais abundantes $\left({ }^{16} \mathrm{O}\right.$ ou $\left.\mathrm{H}\right)$, dada por ${ }^{18} \mathrm{O} /{ }^{16} \mathrm{O}$ para $\delta^{18} \mathrm{O}$ e $\mathrm{D} / \mathrm{H}$ para $\delta \mathrm{D}$ (Craig, 1961).

$\mathrm{O}$ excesso de deutério, $\mathrm{d}$, definido por Dansgaard (1964) como o desvio na reta meteórica $\left(\mathrm{d}=\delta \mathrm{D}-8 \times \delta^{18} \mathrm{O}\right)$, fornece informações adicionais sobre $\mathrm{o}$ ciclo da água. $\mathrm{O}$ seu valor reflete o fracionamento cinético que acontece durante processos de não-equilíbrio tais como evaporação sobre a superfície de oceano (Merlivat \& Jouzel,1979), que é o principal, e evaporação (Stewart,1975) e formação (Jouzel \& Merlivat,1984) da chuva abaixo da base das nuvens.

O excesso de deutério no vapor, sobre a superfície do oceano, cresce com o aumento da temperatura (por aproximadamente $0,35 \% \circ \quad /{ }^{\circ} \mathrm{C}$ ) e com a redução da umidade relativa (por aproximadamente $0,43 \% / \%$ ) (Merlivat and Jouzel, 1979, Johnsen et al., 1989). Segundo Armengaud et al. (1998), ele também fornece informação sobre as condições meteorológicas e sobre a distância das fontes evaporativas que deram origem às chuvas. Desta forma, massas de ar sujeitas a vários episódios consecutivos de condensação e evaporação produzem precipitação com valores elevados de excesso de deutério.

Tabela 1 - Resultados das análises químicas da coleta no período chuvoso: poços amostrados, localização, profundidade, análises químicas, parâmetros físicos e físico-químicos e análises isotópicas (RG: Registro Geral).

\begin{tabular}{|c|c|c|c|c|c|c|c|c|c|c|c|c|c|c|c|c|}
\hline \multirow[b]{2}{*}{ Poço } & \multicolumn{2}{|c|}{ Coordenadas } & \multirow{2}{*}{$\begin{array}{l}\text { Prof. } \\
\text { (m) }\end{array}$} & \multirow[b]{2}{*}{ RG } & \multicolumn{7}{|c|}{ Concentração (mg/L) } & \multirow{2}{*}{$\begin{array}{c}\text { CE } \\
(\mu \mathrm{S} / \mathrm{cm})\end{array}$} & \multirow[b]{2}{*}{ pH } & \multirow{2}{*}{$\begin{array}{c}\mathrm{T} \\
\left({ }^{\circ} \mathrm{C}\right)\end{array}$} & \multirow{2}{*}{$\begin{array}{l}\delta^{18} O \\
(\%)\end{array}$} & \multirow{2}{*}{$\begin{array}{l}\delta^{2} \mathbf{H} \\
(\%)\end{array}$} \\
\hline & Lat. Sul & $\begin{array}{l}\text { Long. } \\
\text { Oeste }\end{array}$ & & & $\mathrm{Ca}^{++}$ & $\mathbf{M g}^{++}$ & $\mathrm{Na}^{+}$ & $\mathrm{K}^{+}$ & $\mathrm{Cl}^{-}$ & $\mathrm{SO}_{4}=$ & $\mathrm{HCO}_{3}^{-}$ & & & & & \\
\hline PI-01 & $32 ' 51,51 "$ & '18’51,75" & 110 & 3445 & 35 & 20 & 3 & 3 & 54 & 15 & 291 & 460 & $\begin{array}{l}6- \\
7\end{array}$ & 9,0 & 3,7 & \\
\hline $\mathrm{PI}-02$ & $9 "$ & 18'23, & 79 & 3446 & 6 & 23 & 3 & 3 & 108 & 23 & 294 & 10 & 7 & 8,5 & $-4,0$ & 26,7 \\
\hline $\mathrm{PI}-03$ & $29^{\prime} 28,40^{\prime \prime}$ & $44^{\circ} 14^{\prime} 45,10^{\prime \prime}$ & 141 & 3449 & 23 & 5 & 58 & 3 & 102 & 14 & 251 & 530 & $\begin{array}{l}6- \\
7\end{array}$ & 29,5 & $-3,6$ & \\
\hline PI-04 & '34’05,00”' & $21 ' 37,09 "$ & 80 & 444 & 1 & 41 & 70 & 4 & 378 & 26 & 45 & 1200 & 8 & 9,0 & $-4,3$ & 29,2 \\
\hline $\mathrm{PI}-05$ & " & $19 ' 27,28$ & 150 & 3442 & 3 & 19 & 46 & 3 & 138 & 19 & 262 & 650 & 8 & 0,0 & $-3,8$ & - \\
\hline PI-06 & 5 & $19^{\prime} 13,87^{\prime \prime}$ & 03 & 3447 & 31 & 14 & 3 & 3 & 28 & 17 & 293 & 400 & 7 & 29,0 & $-3,7$ & \\
\hline $\mathrm{PI}-07$ & $"$ & $18^{\prime} 20,91^{\prime \prime}$ & 112 & 3443 & 29 & 25 & 16 & 3 & 3 & 13 & 299 & 360 & $\begin{array}{l}7- \\
8\end{array}$ & 9,0 & $-4,2$ & 29 \\
\hline $\begin{array}{c}\text { PB- } \\
01\end{array}$ & 1'18,59" & $44^{\circ} 12^{\prime} 57,69^{\prime \prime}$ & 49 & 3434 & 5 & 2 & 2 & 2 & 5 & 5 & 9 & 83 & $\begin{array}{c}4- \\
5\end{array}$ & 28,0 & $-3,7$ & - \\
\hline $\begin{array}{c}\text { PB- } \\
02 \\
\text { PR- }\end{array}$ & $29 ' 19,10 "$ & $44^{\circ} 14^{\prime} 46,97^{\prime \prime}$ & 112 & 3431 & 3 & 2 & 2 & 2 & 10 & 6 & 7 & 79 & $\begin{array}{c}4- \\
5 \\
4\end{array}$ & 27,5 & $-3,6$ & - \\
\hline $\begin{array}{l}\text { PB- } \\
03\end{array}$ & $2^{\circ} 29^{\prime} 58,62^{\prime \prime}$ & $44^{\circ} 14^{\prime} 26,94^{\prime \prime}$ & 70 & 3430 & 3 & 2 & 2 & 2 & 5 & 5 & 5 & 67 & $\begin{array}{l}4- \\
5\end{array}$ & 7,5 & $-3,7$ & 24 \\
\hline $\begin{array}{c}\text { PB- } \\
04\end{array}$ & 31 '04,34" & $44^{\circ} 12^{\prime} 31,69^{\prime \prime}$ & 120 & 3435 & 2 & 6 & 7 & 2 & 16 & 11 & 5 & 163 & $\begin{array}{c}3- \\
4\end{array}$ & 28,5 & $-3,7$ & 22 \\
\hline $\begin{array}{l}\text { PB- } \\
05\end{array}$ & $29^{\prime} 28,45^{\prime \prime}$ & $44^{\circ} 14^{\prime} 45,87^{\prime \prime}$ & 110 & 41 & 3 & 2 & 3 & 2 & 10 & 5 & 12 & 80 & $\begin{array}{l}3- \\
4\end{array}$ & 29,0 & $-3,4$ & 22 , \\
\hline
\end{tabular}




\begin{tabular}{|c|c|c|c|c|c|c|c|c|c|c|c|c|c|c|c|c|}
\hline \multirow[b]{2}{*}{ Poço } & \multicolumn{2}{|c|}{ Coordenadas } & \multirow{2}{*}{$\begin{array}{l}\text { Prof. } \\
\text { (m) }\end{array}$} & \multirow[b]{2}{*}{ RG } & \multicolumn{7}{|c|}{ Concentração (mg/L) } & \multirow{2}{*}{$\begin{array}{c}\text { CE } \\
(\mu \mathrm{S} / \mathrm{cm})\end{array}$} & \multirow[b]{2}{*}{ pH } & \multirow{2}{*}{$\begin{array}{c}\mathrm{T} \\
\left({ }^{\circ} \mathrm{C}\right)\end{array}$} & \multirow{2}{*}{$\begin{array}{l}\delta^{18} \mathrm{O} \\
(\%)\end{array}$} & \multirow{2}{*}{$\begin{array}{l}\delta^{2} \mathrm{H} \\
(\% \circ)\end{array}$} \\
\hline & Lat. Sul & $\begin{array}{l}\text { Long. } \\
\text { Oeste }\end{array}$ & & & $\mathrm{Ca}^{++}$ & $\mathrm{Mg}^{++}$ & $\mathrm{Na}^{+}$ & $\mathrm{K}^{+}$ & $\mathrm{Cl}^{-}$ & $\mathrm{SO}_{4}=$ & $\mathrm{HCO}_{3}^{-}$ & & & & & \\
\hline $\begin{array}{l}\text { PM- } \\
01\end{array}$ & $2^{\circ} 34^{\prime} 33,90^{\prime \prime}$ & $44^{\circ} 13^{\prime} 12,59^{\prime \prime}$ & 74 & 3438 & 3 & 0 & 1 & 2 & 3 & 5 & 13 & 40 & $\begin{array}{c}3- \\
4\end{array}$ & 28,0 & $-3,7$ & $\overline{24,4}$ \\
\hline $\begin{array}{l}\text { PM- } \\
02\end{array}$ & $2^{\circ} 34^{\prime} 25,17^{\prime \prime}$ & $44^{\circ} 13^{\prime} 18,49^{\prime \prime}$ & 81 & 3439 & 3 & 0 & 2 & 2 & 5 & 6 & 8 & 67 & $\begin{array}{l}3- \\
4\end{array}$ & 27,5 & $-3,6$ & - \\
\hline $\begin{array}{l}\text { PM- } \\
03\end{array}$ & $2^{\circ} 34^{\prime} 25,35^{\prime \prime}$ & $44^{\circ} 15^{\prime} 28,63^{\prime \prime}$ & 58 & 3432 & 4 & 1 & 44 & 3 & 22 & 6 & 8 & 107 & $\begin{array}{l}3- \\
4\end{array}$ & 26,0 & $-3,4$ & - \\
\hline $\begin{array}{l}\text { PM- } \\
04\end{array}$ & $2^{\circ} 33^{\prime} 54,76^{\prime \prime}$ & $44^{\circ} 15^{\prime} 06,60^{\prime \prime}$ & 70 & 3436 & 3 & 2 & 4 & 2 & 17 & 19 & 9 & 96 & $\begin{array}{c}3- \\
4 \\
\end{array}$ & 27,0 & $-3,3$ & - \\
\hline $\begin{array}{l}\text { PM- } \\
05\end{array}$ & $2^{\circ} 34^{\prime} 49,48^{\prime \prime}$ & $44^{\circ} 16^{\prime} 22,21^{\prime \prime}$ & 160 & 3433 & 26 & 9 & 5 & 2 & 9 & 16 & 144 & 240 & $\begin{array}{l}5- \\
6\end{array}$ & 27,5 & $-4,0$ & - \\
\hline $\begin{array}{l}\text { PM- } \\
06\end{array}$ & $2^{\circ} 37^{\prime} 29,35^{\prime \prime}$ & $44^{\circ} 19^{\prime} 05,01^{\prime \prime}$ & 78 & 3448 & 8 & 1 & 4 & 2 & 12 & 8 & 8 & 143 & $\begin{array}{l}3- \\
4\end{array}$ & 29,0 & $-3,2$ & 20,5 \\
\hline $\begin{array}{l}\text { PM- } \\
07\end{array}$ & $2^{\circ} 32^{\prime} 56,48^{\prime \prime}$ & $44^{\circ} 15^{\prime} 43,52^{\prime \prime}$ & 156 & 3437 & 8 & 3 & 48 & 2 & 93 & 26 & 146 & 490 & $\begin{array}{l}5- \\
6\end{array}$ & 28,5 & $-3,5$ & 24,0 \\
\hline $\begin{array}{c}\text { PM- } \\
08\end{array}$ & $2^{\circ} 32^{\prime} 54,72^{\prime \prime}$ & $44^{\circ} 10^{\prime} 22,43^{\prime \prime}$ & 81 & 3440 & 4 & 1 & 3 & 2 & 6 & 5 & 8 & 76 & $\begin{array}{l}3- \\
4 \\
\end{array}$ & 28,0 & $-3,6$ & - \\
\hline
\end{tabular}

Tabela 2 - Resultados das análises químicas da coleta no período seco: poços amostrados, localização, profundidade, análises químicas, parâmetros físicos e físicoquímicos e análises isotópicas (RG: Registro Geral).

\begin{tabular}{|c|c|c|c|c|c|c|c|c|c|c|c|c|c|c|c|c|}
\hline \multirow[b]{2}{*}{ Poço } & \multicolumn{2}{|c|}{ Coordenadas } & \multirow{2}{*}{$\begin{array}{l}\text { Prof. } \\
\text { (m) }\end{array}$} & \multirow[b]{2}{*}{ RG } & \multicolumn{7}{|c|}{ Concentração (mg/L) } & \multirow{2}{*}{$\begin{array}{c}\text { CE } \\
(\mu \mathrm{S} / \mathrm{cm})\end{array}$} & \multirow[b]{2}{*}{ pH } & \multirow{2}{*}{$\begin{array}{c}\mathrm{T} \\
\left({ }^{\circ} \mathrm{C}\right)\end{array}$} & \multirow{2}{*}{$\begin{array}{l}\delta^{180} \\
(\%)\end{array}$} & \multirow{2}{*}{$\begin{array}{l}\delta^{2} H \\
(\%)\end{array}$} \\
\hline & Lat. Sul & $\begin{array}{l}\text { Long. } \\
\text { Oeste }\end{array}$ & & & $\mathrm{Ca}^{++}$ & $\mathbf{M g}^{++}$ & $\mathrm{Na}^{+}$ & $\mathbf{K}^{+}$ & $\mathrm{Cl}^{-}$ & $\mathrm{SO}_{4}=$ & $\mathrm{HCO}_{3}^{-}$ & & & & & \\
\hline PI-01 & $2^{\circ} 32^{\prime} 51,51^{\prime \prime}$ & $44^{\circ} 18^{\prime} 51,75^{\prime \prime}$ & 110 & 3514 & 39 & 19 & 86 & 8 & 48 & 13 & 268 & 464 & 7,5 & 30,0 & - & - \\
\hline $\mathrm{Pl}-02$ & $2^{\circ} 33^{\prime} 36,89^{\prime \prime}$ & $44^{\circ} 18^{\prime} 23,52^{\prime \prime}$ & 79 & 3515 & 51 & 42 & 93 & 10 & 145 & 22 & 260 & 733 & 7,0 & 28,5 & 38 & 220 \\
\hline $\mathrm{Pl}-04$ & $2^{\circ} 34^{\prime} 05,00^{\prime \prime}$ & $44^{\circ} 21^{\prime} 37,09^{\prime \prime}$ & 80 & 3516 & 109 & 61 & 127 & 13 & 343 & 14 & 301 & 1146 & 7,3 & 29,0 & - & - \\
\hline $\mathrm{PI}-05$ & $2^{\circ} 33^{\prime} 44,81^{\prime \prime}$ & $44^{\circ} 19^{\prime} 27,28^{\prime \prime}$ & 150 & 3517 & 49 & 19 & 111 & 8 & 130 & 14 & 214 & 675 & 7,7 & 29,5 & 3,9 & 25,2 \\
\hline $\mathrm{PI}-06$ & $2^{\circ} 32^{\prime} 58,65^{\prime \prime}$ & $44^{\circ} 19^{\prime} 13,87^{\prime \prime}$ & 103 & 3518 & 38 & 15 & 79 & 8 & 33 & 10 & 251 & 451 & 7,5 & 29,5 & 3.9 & - \\
\hline $\mathrm{PI}-07$ & $2^{\circ} 34^{\prime} 25,29^{\prime \prime}$ & $44^{\circ} 18^{\prime} 20,91^{\prime \prime}$ & 112 & 3519 & 44 & 19 & 52 & 8 & 8 & 9 & 274 & 385 & 7,6 & 28,5 & - & - \\
\hline PI-08 & $2^{\circ} 32^{\prime} 43,78^{\prime \prime}$ & $44^{\circ} 18^{\prime} 37,28^{\prime \prime}$ & 80 & 3520 & 38 & 13 & 90 & 9 & 59 & 10 & 248 & 507 & 7,7 & 29,0 & $\overline{4,5}$ & 27,1 \\
\hline PI-09 & $2^{\circ} 33^{\prime} 55,39^{\prime \prime}$ & $44^{\circ} 21^{\prime} 39,59^{\prime \prime}$ & 72 & 3521 & 55 & 30 & 69 & 11 & 85 & 10 & 271 & 509 & 7,4 & 30,0 & $\begin{array}{c}- \\
3,6\end{array}$ & $\begin{array}{r}- \\
18,9\end{array}$ \\
\hline $\mathrm{PI}-10$ & $2^{\circ} 34^{\prime} 36,65^{\prime \prime}$ & $44^{\circ} 18^{\prime} 22,45^{\prime \prime}$ & 74 & 3522 & 43 & 29 & 52 & 7 & 9 & 9 & 276 & 415 & 7,5 & 28,0 & ${ }^{-} .6$ & - \\
\hline $\begin{array}{l}\text { PB- } \\
01\end{array}$ & $2^{\circ} 31^{\prime} 18,59^{\prime \prime}$ & $44^{\circ} 12^{\prime} 57,69^{\prime \prime}$ & 49 & 3532 & 6 & 4 & 27 & 2 & 13 & 3 & 12 & 82 & 4,4 & 28,5 & - & - \\
\hline $\begin{array}{l}\text { PB- } \\
02\end{array}$ & $2^{\circ} 29^{\prime} 19,10^{\prime \prime}$ & $44^{\circ} 14^{\prime} 46,97^{\prime \prime}$ & 112 & 3533 & 7 & 2 & 27 & 2 & 14 & 3 & 16 & 79 & 4,9 & 29,0 & - & - \\
\hline $\begin{array}{l}\text { PB- } \\
03\end{array}$ & $2^{\circ} 29^{\prime} 58,62^{\prime \prime}$ & $44^{\circ} 14^{\prime} 26,94^{\prime \prime}$ & 70 & 3534 & 8 & 3 & 29 & 3 & 18 & 3 & 9 & 122 & 4,4 & 29,0 & - & - \\
\hline $\begin{array}{l}\text { PB- } \\
04\end{array}$ & $2^{\circ} 31^{\prime} 04,34^{\prime \prime}$ & $44^{\circ} 12^{\prime} 31,69^{\prime \prime}$ & 120 & 3535 & 4 & 3 & 29 & 3 & 12 & 4 & 40 & 85 & 5,7 & 27,5 & - & - \\
\hline $\begin{array}{l}\text { PB- } \\
05\end{array}$ & $2^{\circ} 29^{\prime} 28,45^{\prime \prime}$ & $44^{\circ} 14^{\prime} 45,87^{\prime \prime}$ & 110 & 3536 & 4 & 3 & 27 & 2 & 14 & 6 & 10 & 88 & 4,8 & 28,5 & - & - \\
\hline $\begin{array}{l}\text { PB- } \\
06\end{array}$ & $2^{\circ} 32^{\prime} 49,92^{\prime \prime}$ & $44^{\circ} 11^{\prime} 33,80^{\prime \prime}$ & 90 & 3537 & 0 & 4 & 27 & 2 & 11 & 3 & 10 & 55 & 4,6 & 28,0 & - & - \\
\hline $\begin{array}{l}\text { PB- } \\
07\end{array}$ & $2^{\circ} 32^{\prime} 42,29^{\prime \prime}$ & $44^{\circ} 11^{\prime} 25,48^{\prime \prime}$ & 90 & 3538 & 0 & 3 & 23 & 2 & 7 & 3 & 11 & 46 & 4,5 & 27,5 & 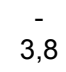 & $\overline{21,5}$ \\
\hline $\begin{array}{l}\text { PB- } \\
08\end{array}$ & $2^{\circ} 29^{\prime} 36,68^{\prime \prime}$ & $44^{\circ} 14^{\prime} 31,03^{\prime \prime}$ & 90 & 3539 & 5 & 2 & 27 & 2 & 13 & 3 & 11 & 83 & 4,6 & 29,0 & - & $-\overline{-}$ \\
\hline $\begin{array}{l}\text { PB- } \\
09\end{array}$ & $2^{\circ} 30^{\prime} 19,13^{\prime \prime}$ & $44^{\circ} 15^{\prime} 07,63^{\prime \prime}$ & 110 & 3540 & 3 & 3 & 28 & 3 & 13 & 5 & 16 & 64 & 4,9 & 29,0 & - & - \\
\hline $\begin{array}{l}\text { PM- } \\
01\end{array}$ & $2^{\circ} 34^{\prime} 33,90^{\prime \prime}$ & $44^{\circ} 13^{\prime} 12,59^{\prime \prime}$ & 74 & 3523 & 0 & 5 & 24 & 1 & 7 & 2 & 10 & 53 & 4,8 & 28,0 & $-3,5$ & - \\
\hline $\begin{array}{l}\text { PM- } \\
03\end{array}$ & $2^{\circ} 34^{\prime} 25,35^{\prime \prime}$ & $44^{\circ} 15^{\prime} 28,63^{\prime \prime}$ & 58 & 3524 & 54 & 15 & 40 & 8 & 22 & 6 & 293 & 454 & 7,5 & 28,0 & - & - \\
\hline $\begin{array}{l}\text { PM- } \\
05\end{array}$ & $2^{\circ} 34^{\prime} 49,48^{\prime \prime}$ & $44^{\circ} 16^{\prime} 22,21^{\prime \prime}$ & 160 & 3525 & 35 & 12 & 52 & 6 & 13 & 5 & 185 & 306 & 7,1 & 28,5 & $-4,3$ & - \\
\hline $\begin{array}{l}\text { PM- } \\
06\end{array}$ & $2^{\circ} 37^{\prime} 29,35^{\prime \prime}$ & $44^{\circ} 19^{\prime} 05,01^{\prime \prime}$ & 78 & 3526 & 10 & 5 & 33 & 6 & 19 & 3 & 12 & 137 & 5,1 & 29,0 & $-3,4$ & - \\
\hline $\begin{array}{l}\text { PM- } \\
08\end{array}$ & $2^{\circ} 32^{\prime} 54,72^{\prime \prime}$ & $44^{\circ} 10^{\prime} 22,43^{\prime \prime}$ & 81 & 3527 & 0 & 4 & 27 & 2 & 12 & 2 & 6 & 84 & 4,3 & 29,0 & - & - \\
\hline $\begin{array}{l}\text { PM- } \\
09\end{array}$ & $2^{\circ} 33^{\prime} 57,33^{\prime \prime}$ & $44^{\circ} 13^{\prime} 16,53^{\prime \prime}$ & 80 & 3528 & 6 & 5 & 34 & 3 & 18 & 3 & 9 & 135 & 4,4 & 28,5 & - & - \\
\hline $\begin{array}{l}\text { PM- } \\
10\end{array}$ & $2^{\circ} 34^{\prime} 24,69^{\prime \prime}$ & $44^{\circ} 13^{\prime} 19,01^{\prime \prime}$ & 80 & 3529 & 0 & 7 & 27 & 3 & 12 & 3 & 11 & 77 & 4,8 & 27,5 & - & - \\
\hline
\end{tabular}




\begin{tabular}{|c|c|c|c|c|c|c|c|c|c|c|c|c|c|c|c|c|}
\hline \multirow[b]{2}{*}{ Poço } & \multicolumn{2}{|c|}{ Coordenadas } & \multirow{2}{*}{$\begin{array}{l}\text { Prof. } \\
\text { (m) }\end{array}$} & \multirow[b]{2}{*}{ RG } & \multicolumn{7}{|c|}{ Concentração (mg/L) } & \multirow{2}{*}{$\begin{array}{c}\mathrm{CE} \\
(\mu \mathrm{S} / \mathrm{cm})\end{array}$} & \multirow[b]{2}{*}{$\mathrm{pH}$} & \multirow{2}{*}{$\begin{array}{c}\mathrm{T} \\
\left({ }^{\circ} \mathrm{C}\right)\end{array}$} & \multirow{2}{*}{$\begin{array}{l}\delta^{180} \\
(\%)\end{array}$} & \multirow{2}{*}{$\begin{array}{l}\delta^{2} H \\
(\%)\end{array}$} \\
\hline & Lat. Sul & $\begin{array}{l}\text { Long. } \\
\text { Oeste }\end{array}$ & & & $\mathrm{Ca}^{++}$ & $\mathrm{Mg}^{++}$ & $\mathrm{Na}^{+}$ & $\mathrm{K}^{+}$ & $\mathrm{Cl}^{-}$ & $\mathrm{SO}_{4}=$ & $\mathrm{HCO}_{3}^{-}$ & & & & & \\
\hline $\begin{array}{c}\text { PM- } \\
11\end{array}$ & $2^{\circ} 34^{\prime} 47,11^{\prime \prime}$ & $44^{\circ} 11^{\prime} 12,03^{\prime \prime}$ & 80 & 3530 & 7 & 0 & 30 & 4 & 21 & 18 & 27 & 133 & 5,4 & 28,0 & $-3,6$ & 20,7 \\
\hline $\begin{array}{c}\text { PM- } \\
12\end{array}$ & $2^{\circ} 34^{\prime} 34,74^{\prime \prime}$ & $44^{\circ} 15^{\prime} 54,21^{\prime \prime}$ & 70 & 3531 & 30 & 9 & 79 & 6 & 24 & 24 & 208 & 389 & 8,0 & 29,0 & $-4,3$ & 26,4 \\
\hline
\end{tabular}

\section{Resultados e Discussão}

\subsection{Hidroquímica}

Os resultados das análises hidroquímicas das amostras coletadas nos período chuvoso e seco, estão mostrados respectivamente, nas Tabelas 1 e 2 . As amostras foram coletadas de três diferentes tipos de armazenamento, identificados pelo perfil geológico como sendo, $\mathrm{PI}$, para poços no aqüífero Itapecuru; PB para poços no aqüífero Barreiras; e $P M$ para poços que explotam os dois aqüíferos (mistura). Perfis de poços dos três diferentes armazenamentos estão mostrados na Figura 2.

Figura 2 - Perfis de poços, dos três diferentes armazenamentos, amostrados na llha de São Luís (Fonte: Fichas técnicas da CAEMA - perfis modificados).

PB-03
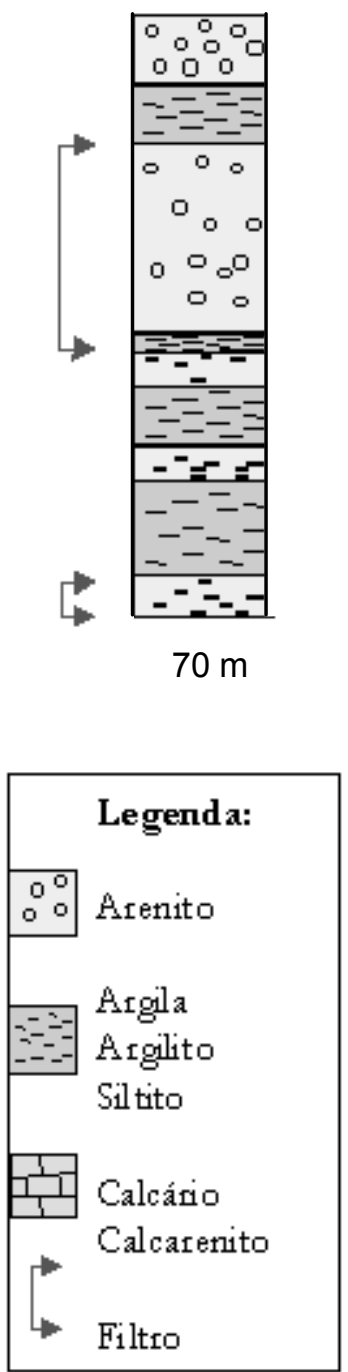

$\mathrm{PI}-05$

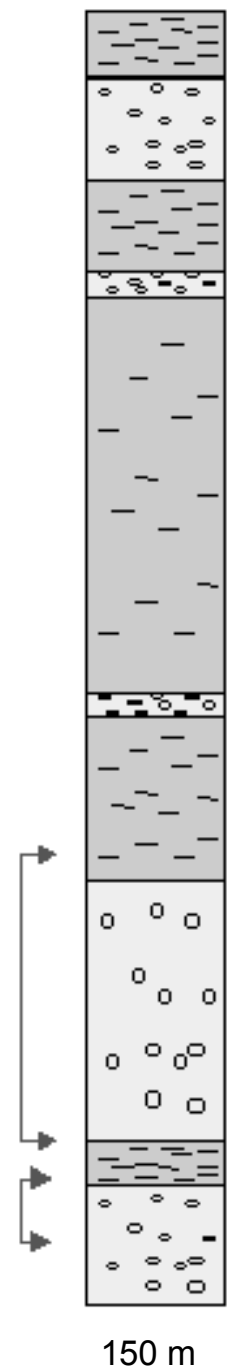

PM-07

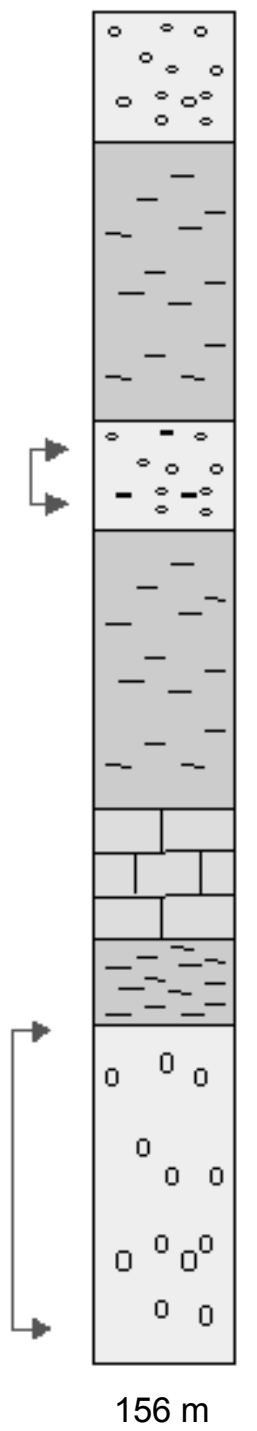

As águas dos dois aqüíferos apresentam baixa salinidade com condutividade elétrica menor que 800 $\mu \mathrm{S} / \mathrm{cm}$, com exceção de duas amostras do poço Pl-04 (Figura 3a). As condutividades elétricas estão em diferentes faixas nos dois 
Rev. Águas Subterrâneas nำ18/ Janeiro 2004

aqüíferos; no aqüífero Barreiras, os valores estão abaixo de $165 \mu \mathrm{S} / \mathrm{cm}$ e no Itapecuru, acima de $360 \mu \mathrm{S} / \mathrm{cm}$. Os poços que explotam os dois aqüíferos apresentam

maior contribuição do Barreiras com exceção de três deles, o PM-03, o PM-05 e o PM-12. 
Figura 3 - (a) Condutividade elétrica e (b) pH, nas amostras dos aqüíferos Itapecuru (PI), Barreiras (PB) e mistura dos dois (PM).

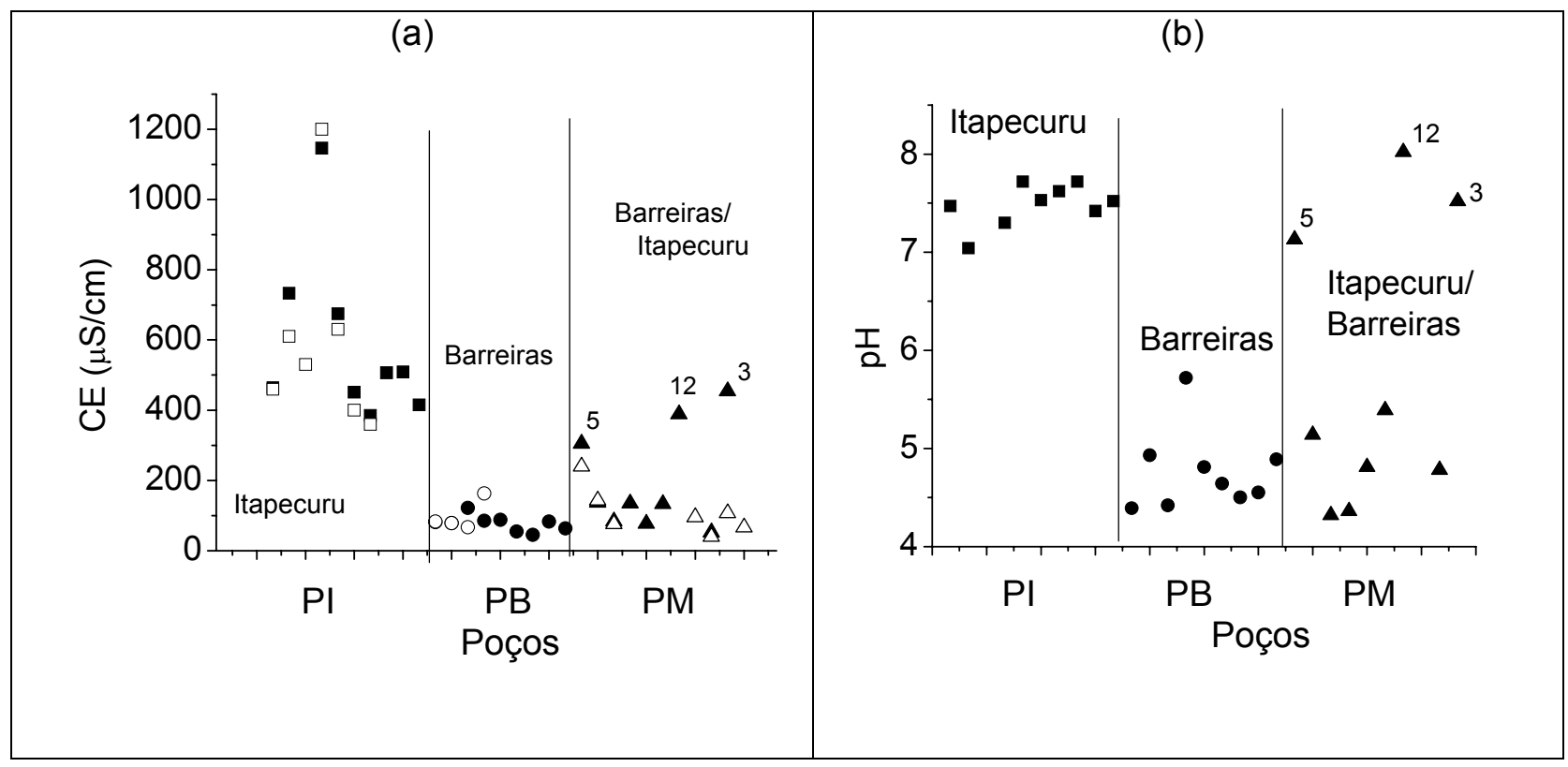

- Barreiras/ltapecuru - período seco

$\triangle$ Barreiras/Itapecuru - período chuvoso

- Barreiras - período seco

- Barreiras - período chuvoso

- Itapecuru - período seco

$\square \quad$ Itapecuru - período chuvoso

Os valores de $\mathrm{pH}$, no período seco (Figura 3b), também apresentam diferentes faixas; entre 7 e 8 no Itapecuru e entre 4 e 6 no Barreiras. Valores de $\mathrm{pH}$ encontrados em amostras do aqüífero livre Barreiras são decorrentes das chuvas regionais que tem, em média, $\mathrm{pH}=4,6$ (Andreae et al., 1988) e são conservados em ambiente de baixa mineralização (as medidas no período chuvoso foram feitas com uso de fita indicadora de $\mathrm{pH}$ ).

Os poços que explotam os dois aqüíferos apresentam águas com $\mathrm{pH}$ característico do Barreiras, com exceção dos poços PM-03, PM-05 e PM-12; esta diferença também pode ser observada na condutividade elétrica. Dos nove poços que explotam os dois aqüíferos, seis deles têm $\mathrm{CE}<140 \mu \mathrm{S} / \mathrm{cm}$, com média de $90 \mu \mathrm{S} / \mathrm{cm}$ e três têm CE $>300 \mu \mathrm{S} / \mathrm{cm}$.

Considerando os valores médios de condutividade elétrica, durante o período seco, de $78 \mu \mathrm{S} / \mathrm{cm}$ para o aqüífero Barreiras e de $587 \mu \mathrm{S} / \mathrm{cm}$ para o aqüífero Itapecuru, os 6 poços que explotam os dois aqüíferos apresentam percentual da contribuição do Barreiras da ordem de $98 \%$ e os três poços
PM-03, PM-05 e PM-12 de, respectivamente, 26,55 e $39 \%$.

Segundo McDonald \& Hardaugh (1988), a contribuição (Qi) de cada zona aqüífera para vazão total $\left(\mathrm{Q}_{\mathrm{T}}\right)$ em um poço, pode ser expressa por,

$$
Q_{i}=\frac{L_{i} k_{i}}{\sum(L k)_{i}} Q_{T}
$$

onde, $L_{i}$ e $k_{i}$ são o comprimento do filtro e a condutividade hidráulica da camada captada i.

O perfil do poço PM-07 mostra que o comprimento do filtro no Barreiras é de $7 \mathrm{~m}$ e no Itapecuru é cinco vezes maior. Observa-se que poços com filtros em diferentes aqüíferos apresentam mistura de água com maior contribuição do horizonte mais produtivo. Como o aqüífero Barreiras apresenta maior produtividade que 0 Itapecuru, a contribuição de suas águas na mistura é dominante, na maioria dos poços. Assim, a instalação de filtros no aqüífero Itapecuru é pouco rentável.

A classificação destas águas quanto ao caráter hidroquímico é apresentada no diagrama de Piper da Figura 4, onde são identificadas as amostras dos aqüíferos 
Itapecuru (PI) e Barreiras (PB) e da mistura dos dois (PM), em cada etapa de coleta. Figura 4 - Diagrama de Piper para os aqüíferos de São Luís, nos períodos seco e chuvoso.

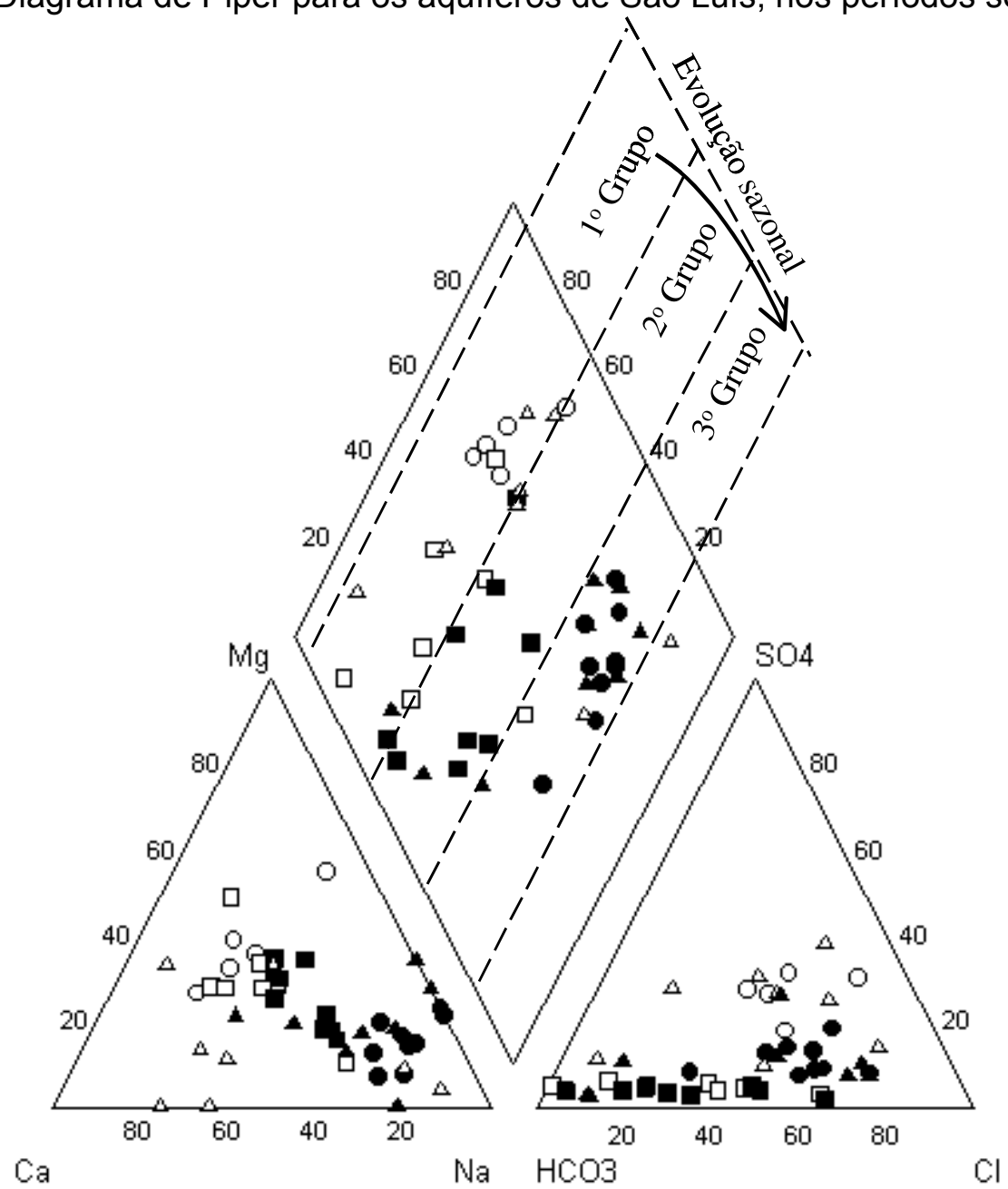

São Luís/MA

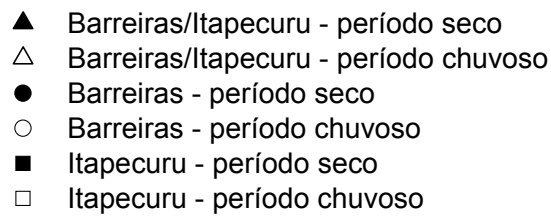

- Barreiras/ltapecuru - período seco

$\triangle$ Barreiras/ltapecuru - período chuvoso

- Barreiras - período seco

- Barreiras - período chuvoso

- Itapecuru - período seco

$\square \quad$ Itapecuru - período chuvoso

Os triângulos de ânions e cátions mostram no aqüífero Barreiras a predominância de águas mistas-mistas, no período chuvoso, evoluindo para cloretadas sódicas, no período seco, em decorrência da presença de aerossóis marinhos que conduzem a águas cloretadas sódicas. No aqüífero Itapecuru, as águas são, predominantemente, bicarbonatadas mistas nos dois períodos.

O losângo do diagrama de Piper separa as águas em três grupos distintos; o primeiro, representado, predominantemente, pelas águas captadas, no período chuvoso, nos aqüíferos Barreiras, Itapecuru e pala mistura Barreira/ltapecuru; o segundo, pelas águas captadas no período seco, provenientes do aqüífero Itapecuru; e o terceiro, pelas águas captadas, no período seco, no aqüífero Barreiras e pela mistura do Barreias/ltapecuru. Estes três grupos representam a evolução hidroquímica sazonal das águas amostradas no aqüífero Barreiras do Grupo 1 para o Grupo 3 e no Itapecuru, do Grupo 1 para o Grupo 2.

Nas Figuras 5 e 6 encontram-se as concentrações de sódio e cloretos, durante os períodos seco e chuvoso, nas amostras do aqüífero Barreiras e mistura 
Barreiras/Itapecuru e do aqüífero Itapecuru, respectivamente.

No período chuvoso, as amostras, têm uma tendência à relação $\mathrm{rNa}^{+}=\mathrm{rCl}^{-}$, com exceção de $\mathrm{PM}-03$ (mistura) e de $\mathrm{Pl}-04$ (aqüífero Itapecuru), indicando a dissolução de aerossóis de origem marinha nas águas de recarga. No período seco os cloretos se mantêm associados ao sódio, mas surge sódio adicional (indicado na Figura 5 pela seta), provavelmente proveniente de troca iônica. No aqüífero Itapecuru, os cloretos apresentam boa correlação com a condutividade elétrica $(R=0,994)$ (Figura 7).

Figura $5-\mathrm{rNa}^{+}$vs. $\mathrm{rCl}^{-}$nas amostras do aqüífero Barreiras $(\mathrm{PB})$ e mistura Barreras/ltapecuru (PM) nos períodos seco e chuvoso.

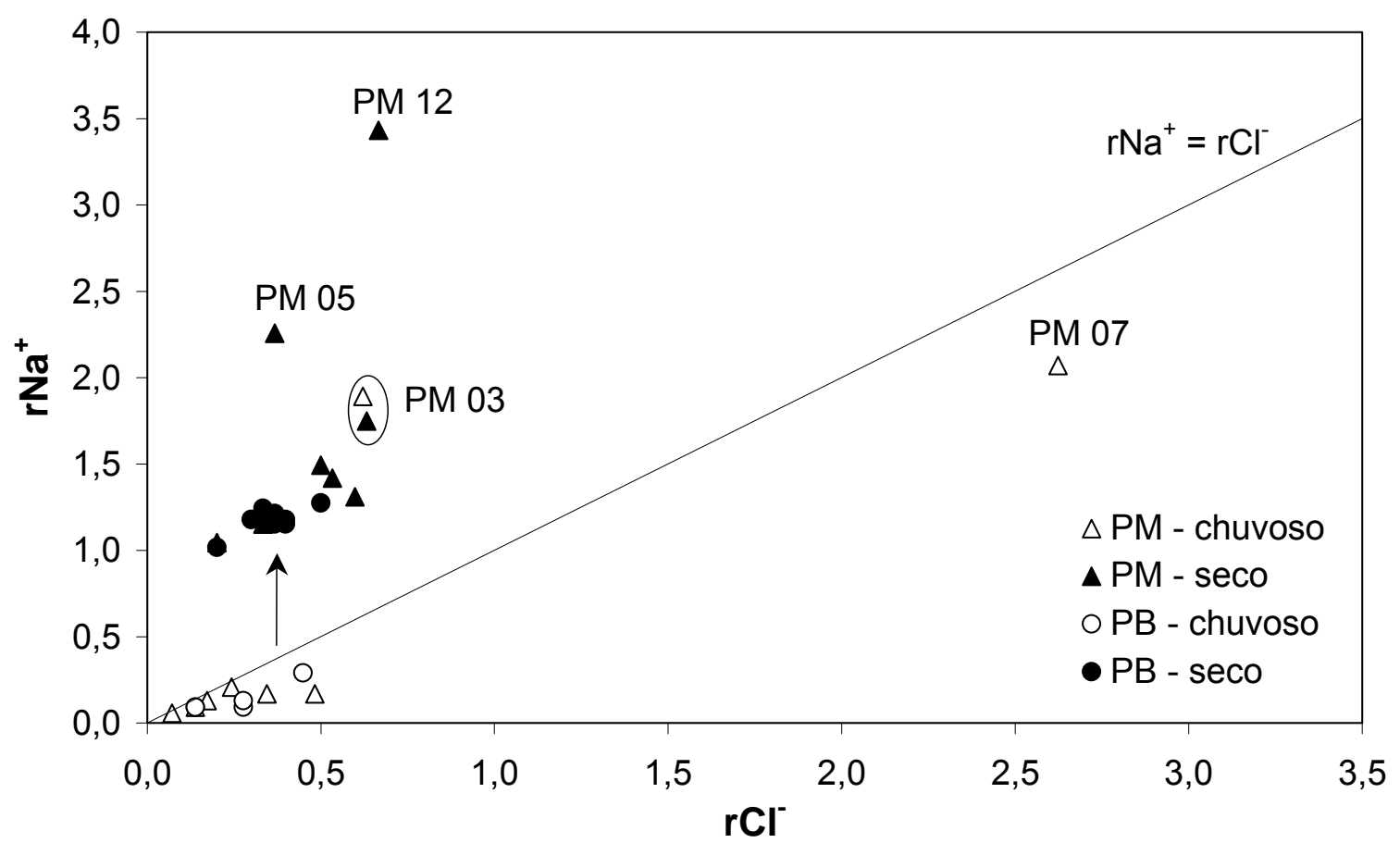

Figura $6-\mathrm{rNa}^{+}$vs. $\mathrm{rCl}^{-}$nas amostras do aqüífero Itapecuru $(\mathrm{PI})$ nos períodos seco e chuvoso.

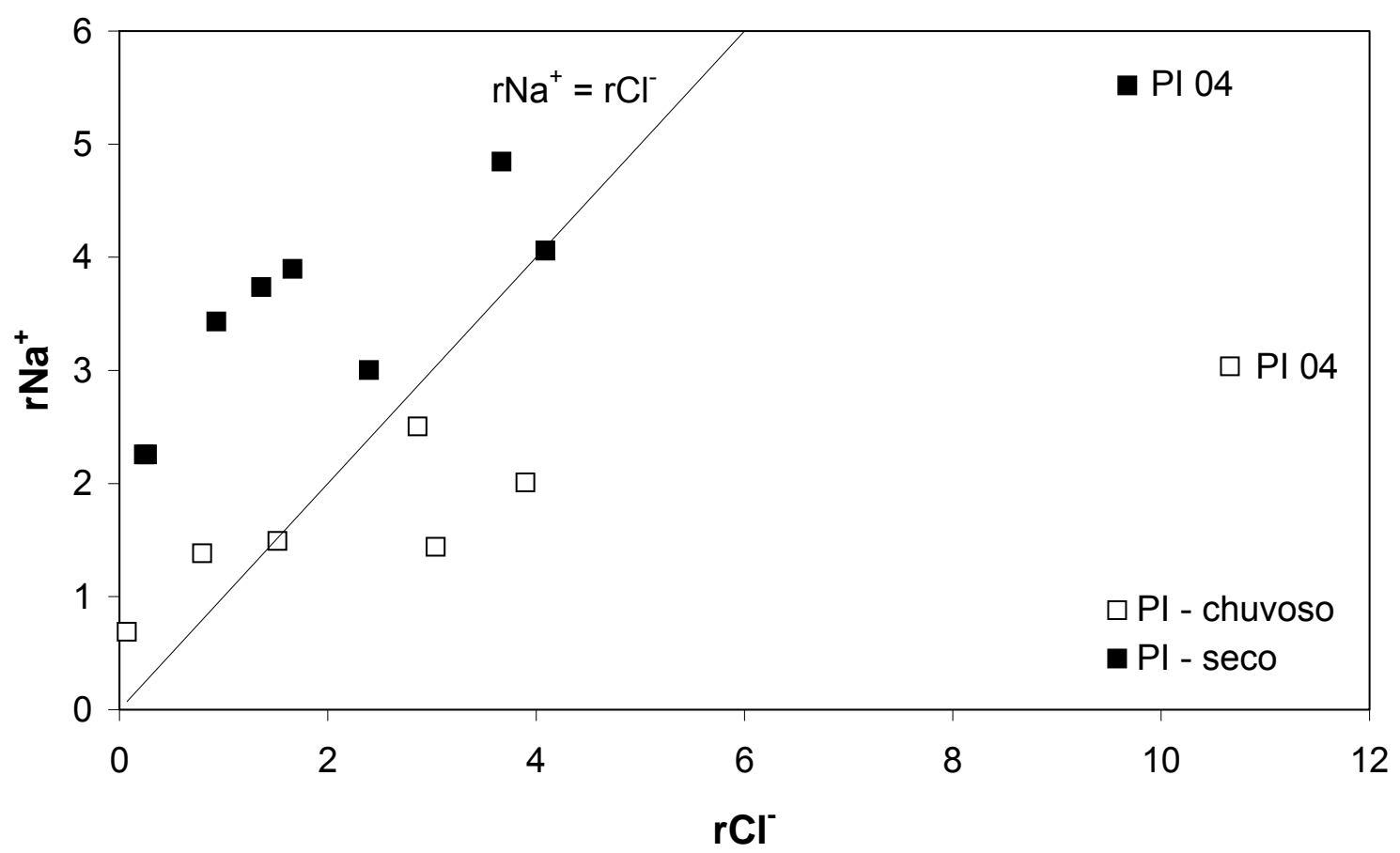


Figura 7 - Condutividade elétrica (CE) vs. $\mathrm{rCl}^{-}$nas amostras do aqüífero Itapecuru.

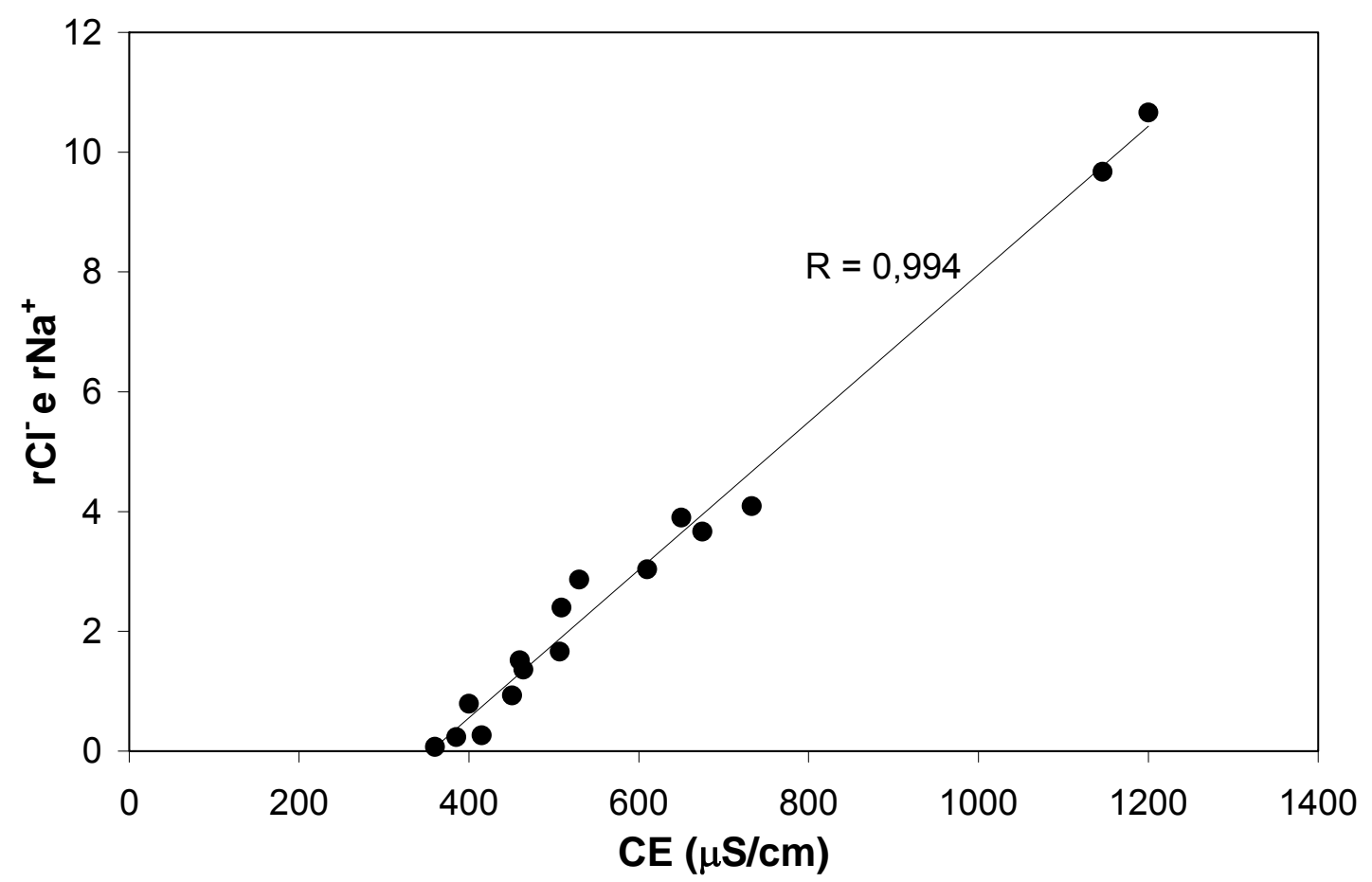

A presença de calcário no aqüífero Itapecuru condiciona a dissolução de calcita durante os períodos chuvoso e seco. A Figura 8 mostra as concentrações de cálcio versus bicarbonatos, em $\mathrm{meq} / \mathrm{L}$, e as funções $\mathrm{rCa}^{2+}=\mathrm{rHCO}_{3}^{-}$e $\mathrm{rCa}^{2+}=2 \mathrm{rHCO}_{3}^{-}$ que representam os limites de dois processos possíveis de dissolução da calcita. O primeiro produzindo águas com razão de $1: 1$ entre os íons $\mathrm{Ca}^{2+}$ e $\mathrm{HCO}_{3}{ }^{-}$, dado pela reação

$$
\mathrm{CaCO}_{3}+\mathrm{H}^{+} \rightarrow \mathrm{Ca}^{2+}+\mathrm{HCO}_{3}^{-}
$$

e o segundo de 1:2, dado pela reação

$\mathrm{CaCO}_{3}+\mathrm{H}_{2} \mathrm{CO}_{3} \rightarrow \mathrm{CaCO}_{3}+\mathrm{H}^{+}+\mathrm{HCO}_{3}^{-} \rightarrow$ $\mathrm{Ca}^{2+}+2 \mathrm{HCO}_{3}^{-}$.

A dissolução de calcita aumenta $\mathrm{opH}$ e a concentração de bicarbonato, o que explica a evolução do $\mathrm{pH}$ abaixo de 6 , no aqüífero Barreiras, e acima de 7 , no Itapecuru; explica, também, a predominância de águas cloretadas no Barreiras e bicarbonatadas no Itapecuru.

Outra provável contribuição de bicarbonato é a dissolução da dolomita, descrita pela equação

$\mathrm{CaMg}\left(\mathrm{CO}_{3}\right)_{2}+\mathrm{H}_{2} \mathrm{CO}_{3} \rightarrow \mathrm{Ca}^{2+}+\mathrm{Mg}^{2+}+$ $4 \mathrm{HCO}_{3}$.

A Figura 8 mostra forte contribuição do cálcio proveniente da dissolução da calcita no aqüífero Itapecuru e que há $\mathrm{HCO}_{3}{ }^{-}$ adicional proveniente, provavelmente, de reações de troca de sódio adsorvido nas argilas pelo cálcio e magnésio em solução na água. As amostras PM-03 e PM-12 coletadas no período seco, PM-07 no período chuvoso e PM-05 nos períodos chuvoso e seco, mostram a existência dos mesmos processos do Itapecuru. 
Figura $8-\mathrm{rCa}^{++}$vs. $\mathrm{rHCO}_{3}{ }^{-}$nas amostras do aqüífero do aqüífero Itapecuru (PI) e mistura Barreiras/Itapecuru (PM) nos períodos seco e chuvoso.

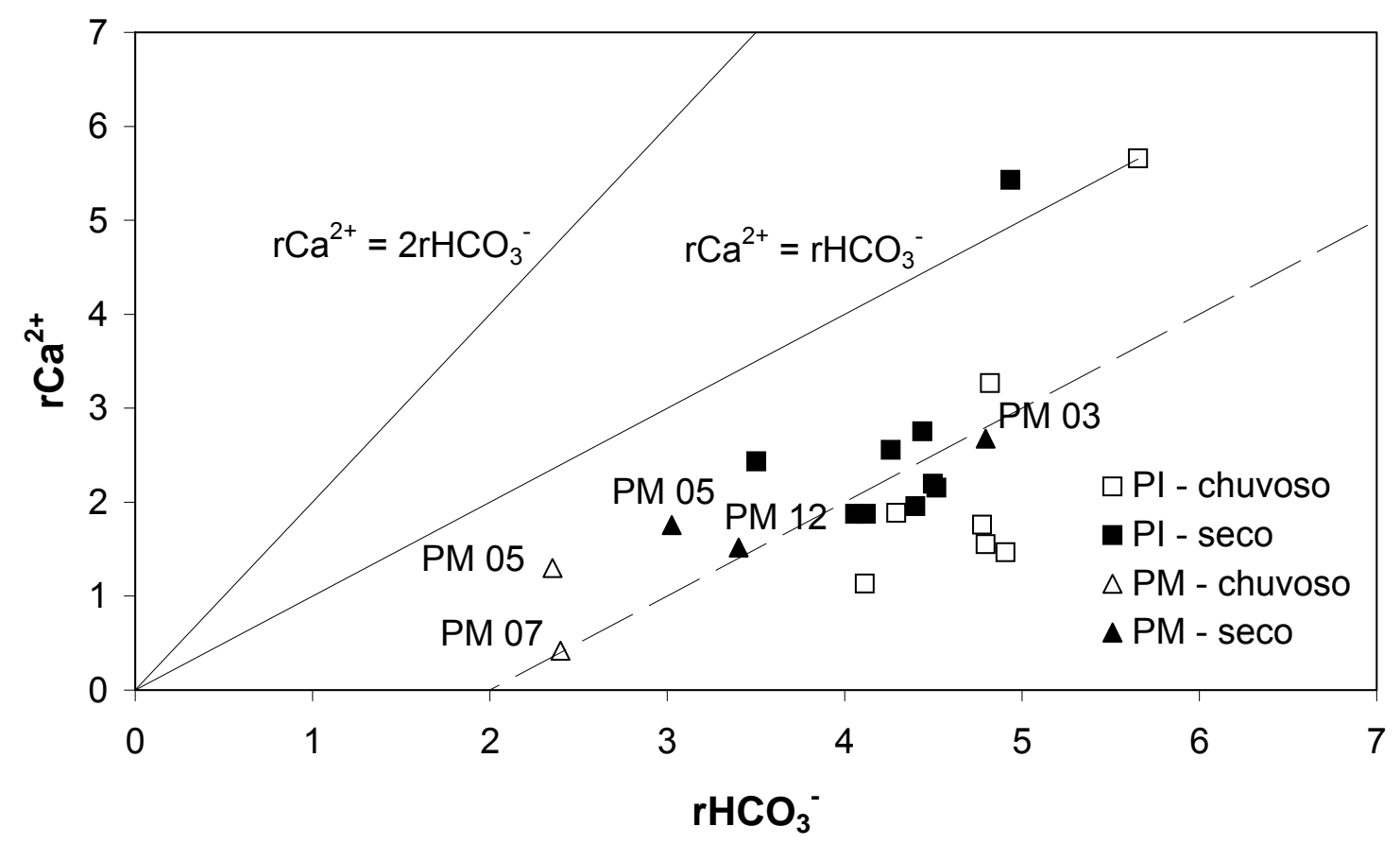

Segundo Thorstenson et al. (1979) e Henderson (1985) a dissolução de calcita e o cálcio trocável com o sódio da argila, produzem elevação de sódio e de bicarbonato na água de acordo com a reação

$$
\begin{aligned}
& \mathrm{CaCO}_{3}+\mathrm{H}_{2} \mathrm{CO}_{3}+2 \mathrm{NaX} \\
& 2 \mathrm{Na}^{+}+2 \mathrm{HCO}_{3}^{-},
\end{aligned}
$$

onde $\mathrm{X}$ representa os argilominerais.

Em águas subterrâneas saturadas em calcita, a produção dos íons cálcio e magnésio ocorre devido a dissolução incongruente de dolomita. Desta forma, os íons derivados desta dissolução tanto precipitam com calcita como também participam dos processos de troca com sódio, de acordo com a reação global

$$
\begin{array}{r}
\mathrm{CaMg}(\mathrm{CO} 3)_{2}+\mathrm{H}_{2} \mathrm{CO}_{3}+\mathrm{NaX} \\
\mathrm{CaCO}_{3}+2 \mathrm{HCO}_{3}^{-}+2 \mathrm{Na}^{+}+\mathrm{MgX} .
\end{array}
$$

Henderson (1985) propõe que a abundancia de cálcio e magnésio em relação ao sódio em solução seja determinada pela equação

$$
R=\frac{\log \left(r \mathrm{Ca}^{2+}+r \mathrm{Mg}^{2+}\right)}{\left(r N a^{+}\right)^{2}} .
$$

A Figura 9 mostra que o cálcio e o magnésio é mais abundante no período chuvoso e menos abundante no período seco. A reta de correlação do período chuvoso tem maior coeficiente angular que a do período seco, indicando que os processo de troca iônica no aqüífero Itapecuru são progressivos, ocorrendo mais acentuadamente no período chuvoso, tendendo ao equilíbrio no período seco. 
Figura 9 - Relação (R, equação 8) proposta por Henderson (1985) vs. $\mathrm{rNa}^{+}$nas amostras do aqüífero Itapecuru.

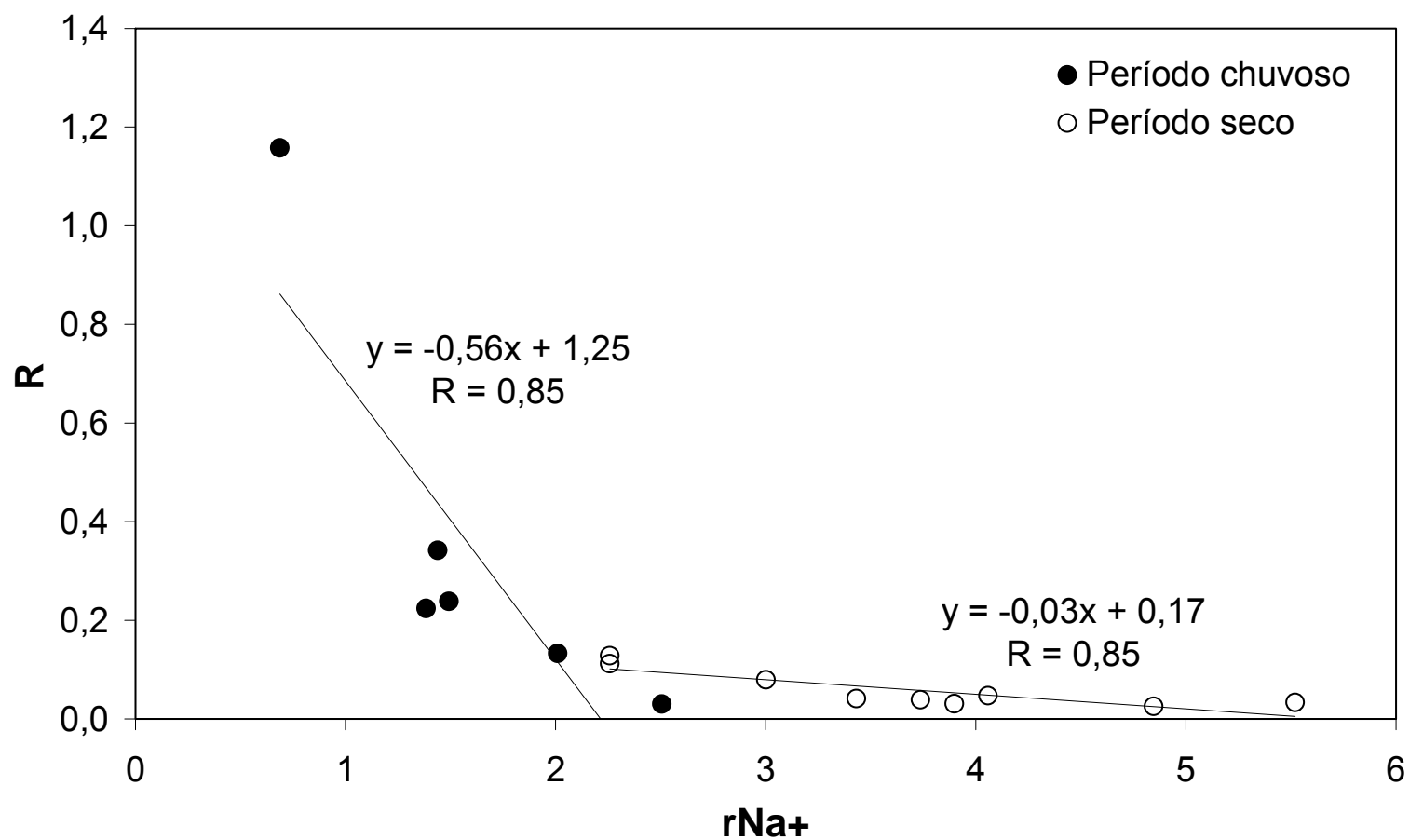

As amostras do Itapecuru e algumas de mistura Barreiras/Itapecuru, apresentam indícios da dissolução de dolomita, por

encontrarem-se em torno da reta $\mathrm{rMg}^{2+}=$ $\mathrm{rCa}^{2+}$, como mostra a Figura 10.

Figura $10-\mathrm{rMg}^{2+}$ vs. $\mathrm{rCa}^{2+}$ nas amostras do aqüífero Itapecuru $(\mathrm{PI})$ e das amostras com excesso de bicarbonato da Figura 6 nos períodos seco e chuvoso.

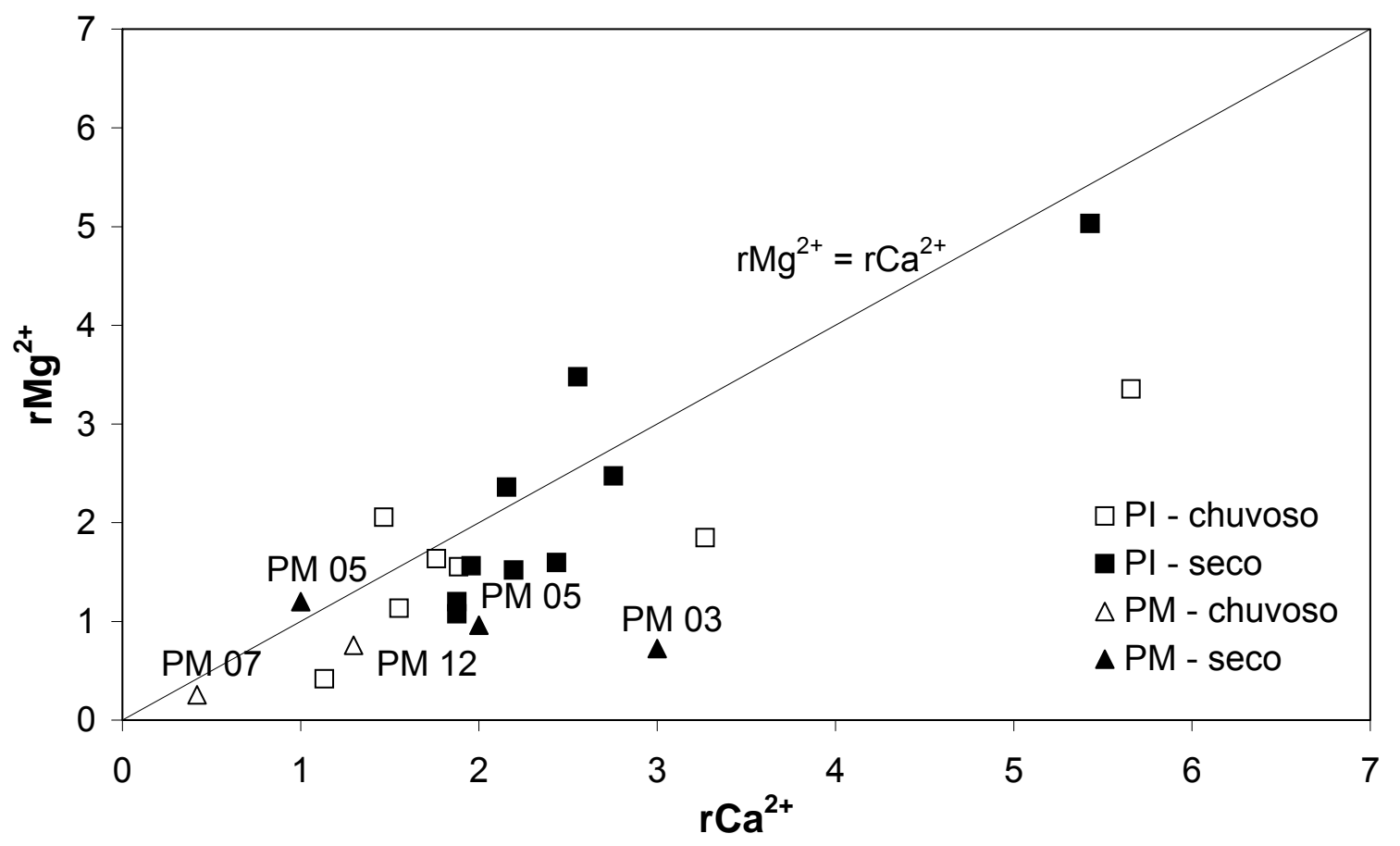


Os índices de saturação da calcita (ISC) e da dolomita (ISD) foram calculados somente para as amostras do período seco por terem medidas de $\mathrm{pH}$ com uso do pHmetro. Na Figura 11, verifica-se uma boa correlação $(R=0,946)$ entre estes índices e que as amostras do aqüífero Itapecuru e as de mistura PM-03, 05 e 12 são saturadas, ou próximas do equilíbrio, em calcita e dolomita.

Figura 11 - Correlação entre os índices de saturação da calcita (ISC) e dolomita (ISD) nas amostras dos aqüíferos Barreiras (PB) e Itapecuru (PI) e na mistura Barreiras/ltapecuru (PM) no período seco.

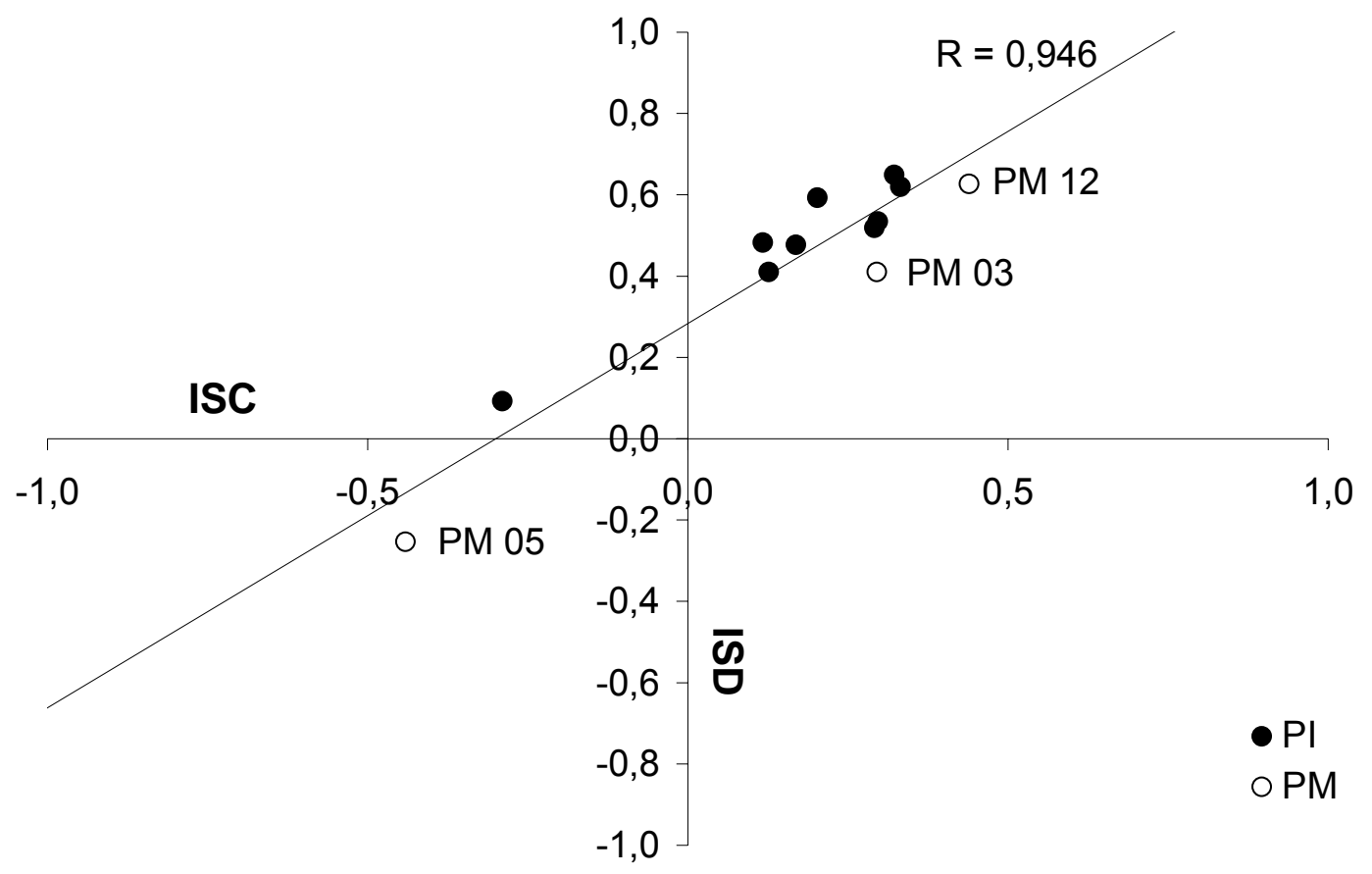

A presença de calcário no aqüífero Itapecuru explica a saturação da calcita e da dolomita. Os poços PM-03, PM-05 e PM-12 são os que recebem maior contribuição do Itapecuru; por isso, apresentam os índices ISC e ISD da mesma ordem que as amostras do Itapecuru.

Como as águas do aqüífero Itapecuru estão saturadas em calcita e dolomita os íons $\mathrm{HCO}_{3}^{-}, \mathrm{Ca}^{2+}{\mathrm{e} \mathrm{Mg}^{2+}}^{2+}$ (Figura 12), não apresentam correlação com a condutividade elétrica (CE) por atingirem o equilíbrio. Esta condição de saturação e a boa correlação entre a CE e o íon $\mathrm{Cl}^{-}(R=0,994$, na Figura 7) indica que o processo de salinização na área ocorre preferencialmente pela dissolução dos minerais calcita $\left(\mathrm{CaCO}_{3}\right)$ e dolomita $\left(\mathrm{CaMg}\left(\mathrm{CO}_{3}\right)_{2}\right)$ e pelos aerossóis de origem marinha, carreados pela chuva $(\mathrm{NaCl})$. 
Figura 12 - Condutividade elétrica (CE) vs. $\mathrm{rCa}^{2+}, \mathrm{rMg}^{2+}$ e $\mathrm{rHCO}_{3}^{-}$nas amostras do aqüífero Itapecuru.

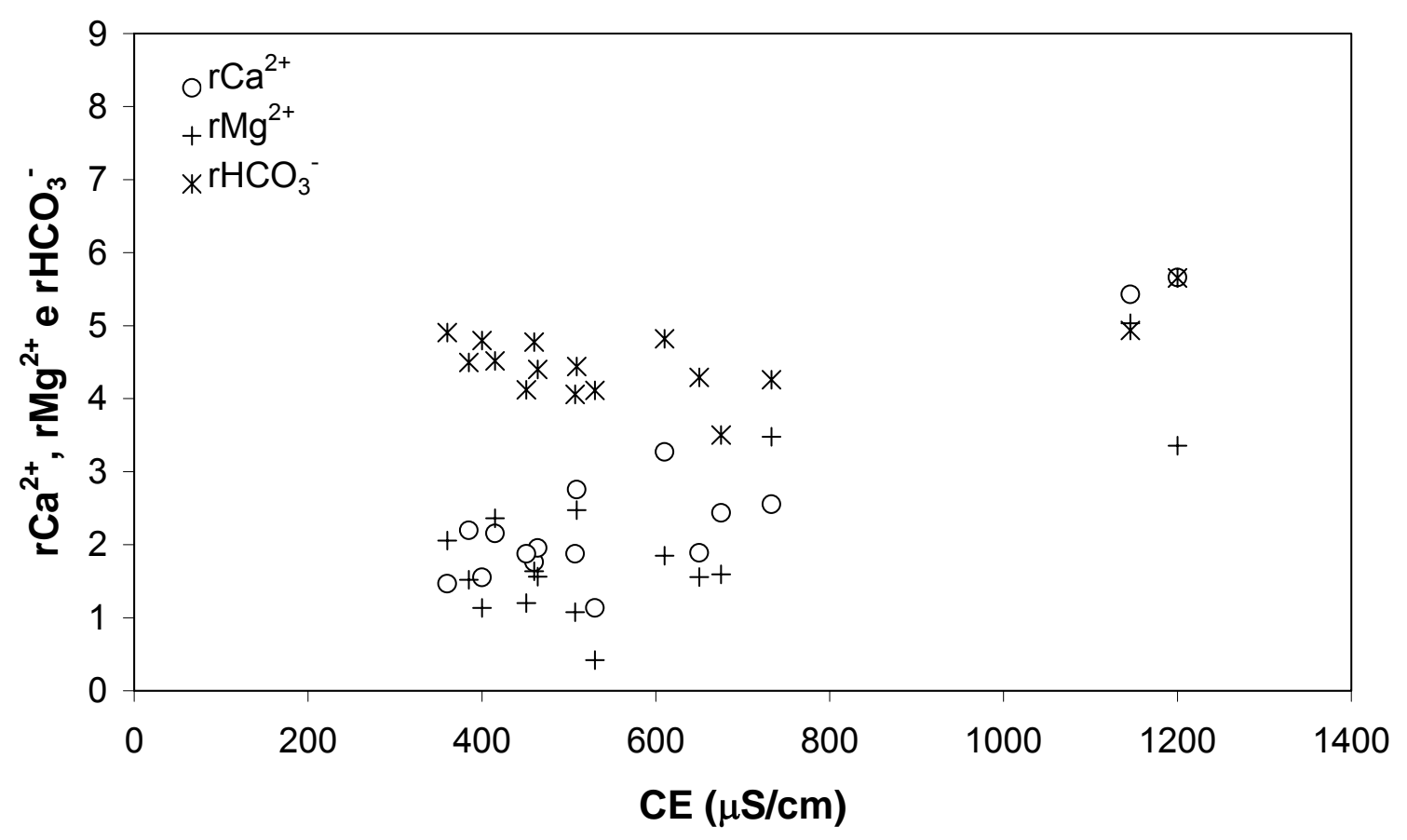

\section{2 - Medidas isotópicas}

chuvoso, estes isótopos estão relacionados,

Medidas de oxigênio-18 e de deutério (Tabelas 1 e 2) foram feitas em amostras coletadas nos aqüíferos e da mistura, no período chuvoso e no período seco. Dados de $\delta^{18} \mathrm{O}$ de todos os poços apresentados na Figura 13a mostram faixas muito próximas nos dois aqüíferos e que os valores mais baixos são encontrados no aqüífero Itapecuru e em algumas águas de mistura.

Tomando separadamente os valores para o período seco e para o período respectivamente, pelas equações $\delta^{2} \mathrm{H}=7,96$ $\delta^{18} \mathrm{O}+4,90$ e $\delta^{2} \mathrm{H}=8,08 \delta^{18} \mathrm{O}+8,47$ (Figura $13 \mathrm{~b})$. Considerando $\mathrm{o}$ erro nas medidas isotópicas de $\pm 0,15 \%$, estas retas apresentam o mesmo coeficiente angular da reta meteórica mundial, $\delta^{2} \mathrm{H}=8 \delta^{18} \mathrm{O}+10$, que representa amostras que não sofreram evaporação. 
Figura 13 - (a) $\delta^{18} \mathrm{O}$ dos poços amostrados nos períodos chuvoso e seco; (b) $\delta^{2} \mathrm{H}$ versus $\delta^{18} \mathrm{O}$.

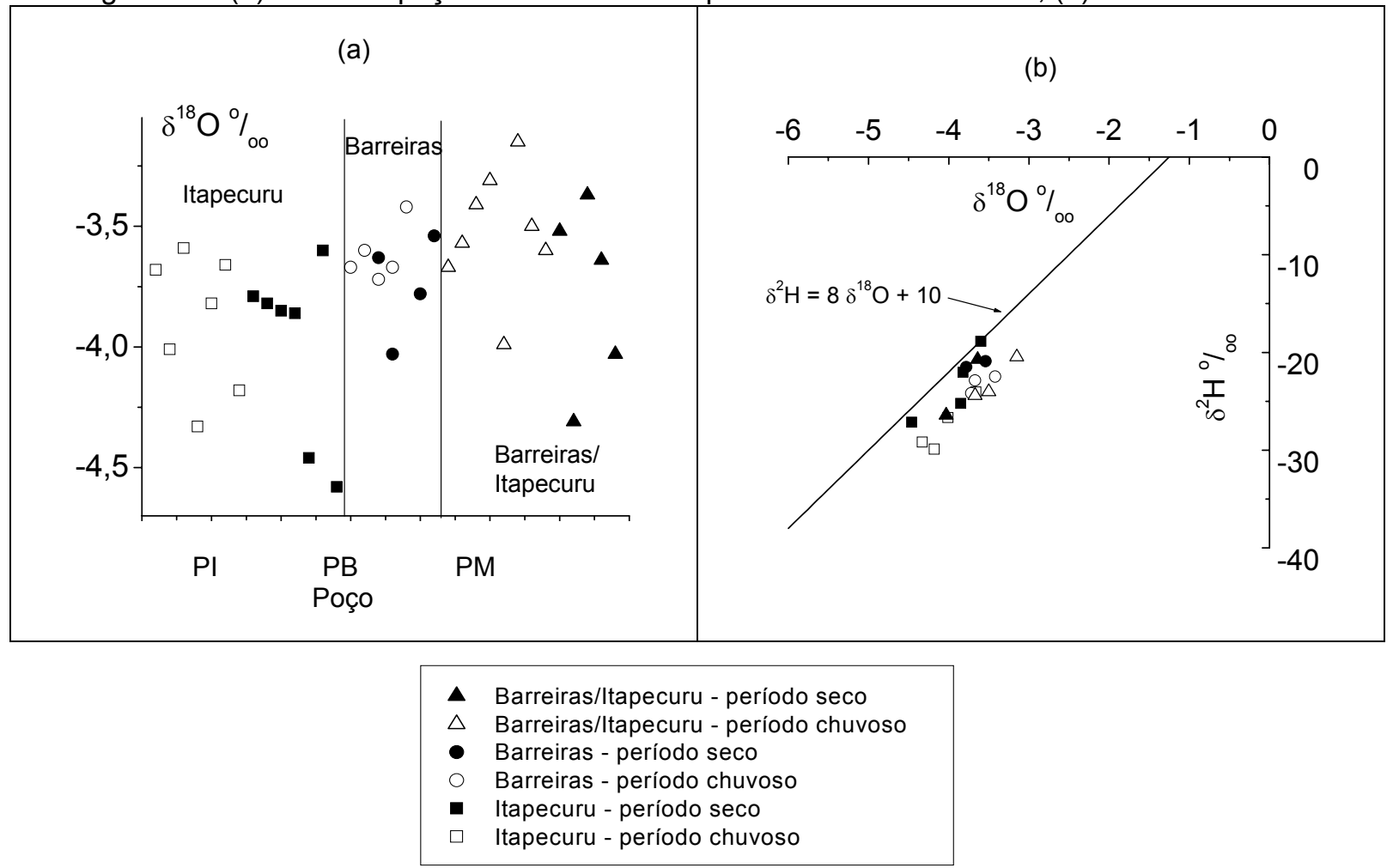

\subsection{1 - Excesso de deutério}

As águas dos aqüíferos Barreiras, Itapecuru e de mistura Barreiras/ltapecuru apresentam efeitos de sazonalidade no excesso de deutério (Tabela 3). Nos períodos chuvoso e seco as médias são de, respectivamente, $5,1 \pm 0,8 \%$ e $8,2 \pm 1,2 \%$. O menor valor no período chuvoso pode ter como causa principal a proximidade da fonte evaporativa formadora das chuvas e como causa secundaria, a re-evaporação durante a queda, ou o aumento no teor de umidade no local de origem da precipitação. No período seco, quando as precipitações e o teor de umidade atmosférica são menores e as temperaturas são maiores, observa-se aumento no excesso de deutério nas águas subterrâneas, indicando contribuição da recarga proveniente de chuvas deste período.

Tabela 3 - Valores de oxigênio-18, deutério e excesso de deutério (d)

\begin{tabular}{|c|c|c|c|c|}
\hline & Poço & $0-18$ & D & d \\
\hline \multirow{10}{*}{ 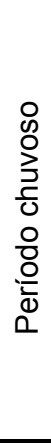 } & PI 02 & $-4,0$ & $-26,6$ & $-5,4$ \\
\hline & PI 04 & $-4,3$ & $-29,2$ & $-5,2$ \\
\hline & PI 06 & $-3,7$ & $-24,1$ & $-5,5$ \\
\hline & PI 07 & $-4,2$ & $-29,9$ & $-3,7$ \\
\hline & PB 03 & $-3,7$ & $-24,2$ & $-5,4$ \\
\hline & PB 04 & $-3,7$ & $-22,9$ & $-6,7$ \\
\hline & PB 05 & $-3,4$ & $-22,5$ & $-4,7$ \\
\hline & PM 01 & $-3,7$ & $-24,4$ & $-5,2$ \\
\hline & PM 06 & $-3,2$ & $-20,5$ & $-5,1$ \\
\hline & PM 07 & $-3,5$ & $-24,0$ & $-4,0$ \\
\hline \multirow{8}{*}{\begin{tabular}{l} 
O \\
$\mathbb{D}$ \\
$\infty$ \\
$\frac{0}{0}$ \\
\hdashline \\
\hdashline \\
0
\end{tabular}} & PI 02 & $-3,8$ & $-22,0$ & $-8,4$ \\
\hline & PI 05 & $-3,9$ & $-25,2$ & $-6,0$ \\
\hline & PI 08 & $-4,5$ & $-27,1$ & $-8,9$ \\
\hline & PI 09 & $-3,6$ & $-18,9$ & $-9,9$ \\
\hline & PB 07 & $-3,8$ & $-21,5$ & $-8,9$ \\
\hline & PB 08 & $-3,5$ & $-20,9$ & $-7,1$ \\
\hline & PM 11 & $-3,6$ & $-20,7$ & $-8,1$ \\
\hline & PM 12 & $-4,3$ & $-26,4$ & $-8,0$ \\
\hline
\end{tabular}




\section{Conclusões}

As águas do aqüífero Itapecuru são mais salinas, com valores de condutividade acima de $360 \mu \mathrm{S} / \mathrm{cm}$ e, predominantemente, do tipo bicarbonatada cálcica enquanto as do Barreiras, são menos salinas, com condutividade abaixo de $165 \mu \mathrm{S} / \mathrm{cm}$ e do tipo cloretada sódica no período seco e no período chuvoso predomina o tipo misto/ misto.

$\mathrm{O} \mathrm{pH}$ nas águas nos dois aqüíferos têm valores completamente distintos; o pH é neutro no aqüífero Itapecuru e ácido no aqüífero Barreiras. $\mathrm{O}$ pH ácido do Barreiras é explicado pelas chuvas ácidas que ocorrem na região e a elevação do $\mathrm{pH}$ das águas do Itapecuru, pela dissolução de calcita, que resulta no caráter bicarbanatado.

Estes resultados indicam 0 efeito natural produzido pela evolução hidrogeoquímica das águas subterrâneas, sugerindo o intemperismo da calcita e da dolomita, por dissolução incongruente, evoluindo do aqüífero Barreiras, com águas de baixo $\mathrm{pH}$ e sub-saturadas nestes minerais, para o aqüífero Itapecuru, com águas de $\mathrm{pH}$ elevado e saturadas em calcita e dolomita.

As condições geológicas nos dois aqüíferos levam a processos distintos de dissolução. Observa-se uma menor salinidade no aqüífero Barreiras, mais produtivo, e uma maior salinidade no aqüífero Itapecuru, menos produtivo. O aqüífero mais produtivo apresenta circulação rápida das águas com menor tempo de contato com as rochas; e o menos produtivo uma condição inversa a anterior, levando a uma maior salinidade de suas águas.

A recarga dos dois aqüíferos é rápida sem permitir evaporação antes de infiltrar; as águas mudam significativamente 0 caráter químico do período chuvoso para o período seco. A presença de águas, isotopicamente semelhantes, nas duas etapas de coleta mostra que o Itapecuru é semi-confinado permitindo interconexão entre os dois aqüíferos.

A presença de águas cloretadas sódicas nos dois aqüíferos deve-se à localização da área na costa, sendo influenciadas pela presença de aerossóis marinhos.
Os

poços

exploram,

predominantemente, o aqüíferos Barreiras. Dos poços que são considerados como explorando água de mistura dos dois aqüíferos, somente três deles recebem contribuição significativa do Itapecuru; os demais recebem, praticamente, somente águas do Barreiras.

Os coeficientes angulares das retas de correlação $\delta^{2} \mathrm{H} \times \delta^{18} \mathrm{O}$ indicam que as amostras não sofreram evaporação. $O$ excesso de deutério apresenta efeito de sazonalidade com menor valor no período chuvoso e mais elevado no período seco, quando as precipitações e o teor de umidade atmosférica são menores e as temperaturas são maiores. $O$ aumento no excesso de deutério nas águas subterrâneas durante o período seco indica contribuição da recarga proveniente de chuvas deste período.

\section{Agradecimentos}

Ao CNPq e à FUNCAP (Fundação Cearense de Apoio ao Desenvolvimento Científico e Tecnológico), pelo apoio financeiro.

\section{Referências Bibliográficas}

ANDREAE et al. 1988. In: Martins, C. R. \& Andrade, J. B. Química atmosférica do enxofre (IV): emissões, reações em fase aquosa e impacto ambiental. Quim. Nova, 25 (2): 259 - 272, 2002.

ARMENGAUD, A., KOSTER, R., JOUZEL, J., CIAIS, P. 1998. Deuterium excess in Greenland snow: analysis with simple and complex models. Journal Geophysical Research, 103, 8947 - 8953.

COSTA, W. D. 1995. Água subterrânea e o desenvolvimeto sustentável do semi-árido nordestino. In: Projeto Áridas: uma estratégia de desenvolvimento sustentável para o Nordeste. Brasília: Secretaria de Planejamento, Orçamento e Coordenação da Presidência da República.

CPRM (Companhia de Pesquisa de Recursos Minerais). 2000. Programa de Levantamentos Geológicos Básicos do Brasil, São Luís SE/NE Folhas SA. 23-X e SA. 23-Z. Estados do Maranhão e Piauí, Brasília, CD-ROM.

CRAIG, H. \& LAL, D. 1961. Standard for reporting concentrations of deuterium 
and oxygen-18 in natural waters. Science, 133, 1833-1834.

DA ILHA DE SÃO LUÍS/MA - Brasil. Dissertação de Mestrado. Departamento de Física - UFC. 92 p.

DANSGAARD, W.1964. Stable Isotopes in Precipitation. Tellus, 16, $436-468$.

HENDERSON, T. 1985. Geochemistry of ground water in two sandstone aquifer systems in the Northern great plains in parts of Montana and Wyoming. U. S. Geol. Surv. Prof. Paper 1402-C, 84 p.

JOHNSEN, S. J., DANSGAARD, W., WHITE, J. W. C. 1989: The origin of arctic precipitation under present and glacial conditions. Tellus, 41B, 452-468.

JOUZEL, J., MERLIVAT, L. 1984.Deuterium and oxygen 18 in precipitation: modeling of the isotopic effects during snow formation. Journal Geophysical Research, 89, 11749 - 11757.

MCDONALD, M. G.; HARBAUGH, A. W. 1988. A modular three-dimensional finite-difference grond-water flow model. Washington: Techniques of Water Resources Investigations of the U.S. Geol. Survey. Book 6, chap. A1.
MERLIVAT, L., JOUZEL, J. 1979.Global climatic interpretation of the DeuteriumOxygen 18 relationship for precipitation. Journal Geophysical Research, 84, $5029-5033$.

PEREIRA, L. 2002. Caracterização Isotópica e Hidroquímica das Águas Subterrâneas

SOUSA, S. B. 2000. Sistema Aquífero da Ilha do Maranhão, I Congresso Mundial Integrado de Águas Subterrâneas, Fortaleza/CE, ABAS-CDROM.

STEWART, M. K. 1975. Stable isotope fractionation due to evaporation and isotopic exchange of falling water drops: Application to atmospheric processes and evaporation of lakes. Journal of Geophysical Research, 80, 1133 1146.

THORSTENSON, D.C., FISHER, D.W., CROFT, M.G. 1979. The geochemistry of the Fox Hills-basal hell creek aquifer in Southwestern North Dakota and Northwestern South Dakota. Water Resour. Res. 15, 1479 - 1498. 